\title{
Lend Global, Fund Local? Price and Funding Cost Margins in Multinational Banking*
}

\author{
Rients Galema ${ }^{1}$, Michael Koetter ${ }^{2,3,4}$ and Caroline Liesegang ${ }^{5}$ \\ ${ }^{1}$ Utrecht University, ${ }^{2}$ Frankfurt School of Finance and Management, ${ }^{3}$ Halle Institute for Economic \\ Research (IWH), ${ }^{4}$ Deutsche Bundesbank, and ${ }^{5}$ European Central Bank
}

\begin{abstract}
In a proposed model of a multinational bank, interest margins determine local lending by foreign affiliates and the internal funding by parent banks. We exploit detailed parent-affiliate-level data of all German banks to empirically test our theoretical predictions in pre-crisis times. Local lending by affiliates depends negatively on price margins, the difference between lending and deposit rates in foreign markets. The effect of funding cost margins, the gap between local deposit rates faced by affiliates abroad and the funding costs of their parents, on internal capital market funding is positive but statistically weak. Interest margins are central to explain the interaction between internal capital markets and foreign affiliates lending.
\end{abstract}

JEL classification: F33, G21

\section{Introduction}

What role do internal capital markets of multinational banks play for the local lending by affiliates in foreign markets? In response to the financial crisis of 2008, US multinational banks actively managed the liquidity within their internal capital markets on a global scale (Cetorelli and Goldberg, 2012b, 2012c). But whereas the role of multinational banks for

* This article was written during visits of the authors to the Deutsche Bundesbank, which we thank for its hospitality and data access. We also thank an anonymous referee, the editor Steven Ongena as well as Claudia Buch, Lammertjan Dam, Falko Fecht, Galina Hale, Kaddee Russ, Christoph Schröder, and seminar participants at the Pacific Rim Meetings of the WEA, the International Banking workshop at Frankfurt School, the EEA meetings in Gothenburg, the IMF/DNB conference on International Banking, and the FEBS conference at the University of Surrey. We are particularly indebted to Cornelia Kerl for kind assistance with the construction of the internal capital market flow data. We also thank Maximillian Eber for suggesting a routine to combine data sets without common identifiers. Financial support from the European Commission, Research Directorate General as part of the 7th Framework Program, Theme 8: Socio-Economic Sciences and Humanities. Grant Agreement no: 244709 (the INDICSER project) is gratefully acknowledged (to R.G.). The opinions expressed in this article are those of the authors only and not necessarily those of any affiliated institution. All remaining errors are our own. 
the international transmission of shocks and policy is fairly well understood, the interaction between liquidity management by parents and the lending behavior of their foreign affiliates, in particular under non-crisis conditions, remains unclear. We propose a simple theory of multinational banks and provide empirical evidence based on observed internal capital market flows to explain the interaction between the internal management of funding resources and foreign lending via affiliates in tranquil times.

The first contribution of this article is to propose a stylized model that explains choices of a multinational banking firm, henceforth the "parent", for both local lending by the affiliate and parent funding. We adapt a Monti-Klein model to explain how a parent operates affiliates abroad (foreign markets). In analogy to Park and Pennacchi (2009), local lending by the affiliate is funded by a combination of deposits collected in the foreign market (local deposits) and internal capital market funds received from parents (parent funding). Local lending by the affiliate depends on the ability to generate profits in foreign markets, gauged by price margins which equal the difference between loan and deposit rates in each foreign market. We assume in line with the Monti-Klein model imperfect competition in foreign loan markets and well-behaved demand functions. Thereby, foreign affiliates can realize markups, giving rise to a negative relationship between price margins and equilibrium levels of local lending by the affiliate. Parent funding, in turn, depends positively on a cost margin, which reflects the difference between local deposit rates in foreign markets and the funding costs of parents in their home market. Parents choose local lending and parent funding of each individual affiliate given the price and cost margin and the respective choices for all other affiliates when maximizing parent profits. Thereby, we formalize the notion put forward by Cetorelli and Goldberg (2012c) and Frey and Kerl (2015) that parents manage liquidity on a global scale and analyze how internal capital markets interact with local lending by parents' affiliates.

Modeling different interest rate margins that drive local lending by the affiliate and parent funding choices is an approach that is closest in spirit to Cetorelli and Goldberg (2012c). For US banks they show that internal capital market flows between affiliates and parents were used actively to smooth liquidity excesses and shortages in different regional markets on a global scale during the 2008 financial crisis. Parents operate according to a locational pecking order: A shock to the parent balance sheet causes them to tap traditional funding locations more extensively, but important affiliate lending locations continue to receive parent funding. The existence of such core funding and core lending markets implicitly depends on the relative importance of these markets compared with other markets that the parent serves. Our model helps to hypothesize explicitly that local lending by the affiliate is driven by the price margin that can be earned in foreign markets, and the amount of parent funding available to support this lending conditional on the parent's funding advantage reflected by funding cost margins.

Theoretical models of multinational banks are generally scarce. De Blas and Russ (2013) develop a general equilibrium framework featuring heterogeneous banks that compete with another through their choice of interest rates to supply loans abroad. This structure is similar to our use of price margins to explain local lending by affiliates. But it does not incorporate the interplay between lending choices and parent funding allocation through internal capital markets, which is central to our study. Niepmann (2013, 2015) models heterogeneous banks in a general equilibrium framework to explain different types of international banking activity (e.g., cross-border lending versus FDI) as a consequence of efficiency and factor endowments differences between banking systems at home and 
abroad. But she does not focus on the choices of parents how to fund foreign affiliates as a source of such efficiency differences, which is what we model and test empirically.

Our second contribution is to provide empirical evidence on the interaction between internal capital markets and local lending by affiliates under "normal" circumstances in tranquil times. Earlier evidence on this interaction is largely confined to the differences between local banks and bank holding companies in the USA. Results by Campello (2002) and Gambacorta (2005) suggest that the availability of parent funding alleviates funding constraints, relative to the limits faced by stand-alone banks. Lifting funding constraints does not necessarily imply more lending though (Ashcraft, 2006). Cremers, Huang, and Sautner (2011) show that regional branches of a large European bank holding group are more likely to receive internal capital market funds if they are located closer to headquarters and possess more voting rights within the group. Differences in internal capital market access thus can significantly explain differences in lending. We investigate whether and to what extent such internal capital market dynamics apply to parents' global affiliate networks. As such, our article is closely related to the empirical work of Cetorelli and Goldberg, who investigate how US monetary policy transmits via parents to markets outside the USA (Cetorelli and Goldberg, 2012a), how local branches of non-US banks respond to funding shocks of their foreign parents (Cetorelli and Goldberg, 2012b), and how US parents actively manage liquidity within their internal capital markets (Cetorelli and Goldberg, 2012c).

To this end, we derive two reduced form equations for local lending by affiliates and parent funding, which depend on price and funding cost margins. To acknowledge that local lending by the affiliate depends on choices by headquarters about the lending and funding of other affiliates of the parent, we also account for the lending and price margins of all other affiliates within a certain parent. Similarly, we account for parent funding and funding cost margins of all other affiliates within a parent to explain net funding. In addition, we specify affiliate- and country-specific control variables, parent $\times$ year, and country-fixed effects. Thereby, we explain the variation in local lending by affiliates and parent funding across affiliates of identical parents in a given country over time.

The empirical evidence comes from detailed data about the local lending by all German parents' affiliates to households and non-financial corporations and internal capital market flows between parents and foreign affiliates, combined with affiliate-level information and macroeconomic data from fifty-eight countries between 2003 and 2007. Contrary to most prior studies, we can observe internal capital market flows from the External Position Report data of Deutsche Bundesbank. ${ }^{1}$ These data also feature detailed financial accounts of foreign affiliates, by year and by country (Buch, Koch, and Koetter, 2011b). The sampled countries account for approximately $90 \%$ of all local lending by foreign affiliates of German parents. Thus, we rely neither on indirect measures of internal capital markets, such as imputed internal capital market flows from ownership data in Bankscope (De Haas and Van Lelyveld, 2010), nor on partial perspectives of parents' international activities, such as syndicated lending (De Haas and Van Horen, 2013). We focus on lending to households and corporates in foreign markets, which are located in the country where the affiliate resides as well. By combining these data with financial accounts reported to the prudential supervisor and macro-information, we control for foreign affiliate and foreign credit market traits. 
We find a negative relationship between larger price margins and the local lending by the affiliate. This result is in line with our theoretical model. Parents maximize profits in incomplete foreign loan markets by realizing larger price margins at lower equilibrium levels of local lending by the affiliate, resembling monopolistic competition as in Monti-Klein (see Freixas and Rochet, 2008) and credit rationing à la Stiglitz-Weiss (1981). However, branches and affiliates that fund local lending solely with local deposits exhibit a small, but significant positive total effect in an interaction model. These foreign affiliates tend to be very small and focused on retail lending, therefore possibly being price takers in foreign markets rather than monopolistic competitors. Thus, they might expand local lending in response to larger price margins because without access to the internal capital markets of their parents they are not able to undercut local credit competition. In turn, affiliates belonging to the largest parents exhibit both a negative direct and interaction effect of price margins on local lending by the affiliate. The baseline effects of larger average price margins and local lending of other affiliates within the same parent are also negative.

Regarding parent funding, we estimate a positive relationship with funding cost margins, which is in line with theory. However, this effect is statistically not significant in baseline regressions. Only when we account for regional heterogeneity in terms of Organization of Economic Cooperation and Development (OECD) and European Monetary Union (EMU) countries by means of an interaction model, funding cost margins exhibit a positive and statistically significant effect. For our sample of foreign affiliates of German parents during tranquil pre-crisis times, these results suggest that potential funding cost advantages of parents may be present, but are statistically weak. Whereas the effect of funding cost margins of other affiliates is only weakly significant, the volume of parent funding routed to other affiliates reduces parent funding to individual affiliates significantly. This result therefore suggests that parents do manage liquidity indeed actively and on a global scale.

The main results are insensitive when we allow for dependence between local lending by the affiliate and parent funding equations, the presence of a potential selection bias against foreign markets entry through affiliates, alternative fixed effect and control variable specifications, and other measures of local lending by the affiliate and parent funding.

Section 2 presents the theoretical model and the empirical specifications to explain local lending by the affiliate and internal funding as functions of the price and funding cost margins. Section 3 describes the data and we discuss the results in Section 4. Section 5 concludes.

\section{Theory and Methodology}

We develop a simple model à la Monti-Klein (Freixas and Rochet, 2008, p. 78) in which a parent operates multiple affiliates in foreign markets. Starting with the foreign affiliate's profit function, the model explains how each foreign affiliate chooses local lending in its market using both local deposits and parent funding. Each foreign affiliate earns a price margin on the amount of local lending by the affiliate funded by local deposits and a funding cost margin on the amount of local lending by the affiliate funded by the parent. The parent maximizes total profits as the sum of foreign affiliate profits.

Parents may maximize profits if each foreign affiliate maximizes its own profits. But if local loan and deposit market conditions differ across foreign markets, for instance in terms of financial shocks, price elasticities of loan demand and deposit supply, real business 
cycles, regulation, and other factors, the main benefit of an internal capital market is the opportunity to reallocate funds across markets. Thereby, internal capital markets give rise to phenomena such as "core lending" and "core funding" markets in Cetorelli and Goldberg (2012b, 2012c). Headquarters then set local lending by the affiliates and internal capital market funding such that parents' total profits are maximized rather than individual affiliate profits. Local lending and parent funding at one of the parent's affiliates is then no longer independent from local lending and parent funding at its other affiliates.

\subsection{Theory}

Consider a foreign affiliate $j$ that originates local loans $L_{i j}$ at rate $R_{i j}^{L}$ in its foreign market. It has a parent $i$ that partially funds its lending. The foreign affiliate's profit function is defined as:

$$
\pi_{i j}=R_{i j}^{L} L_{i j}-R_{i j}^{F} F_{i j}-R_{i j}^{D} D_{i j}
$$

Local lending in the foreign market is funded with $F_{i j}$ provided by parent $i$ to foreign affiliate $j$ at rate $R_{i j}^{F}$ and with local deposits raised by the foreign affiliate $D_{i j}$ at rate $R_{i j}^{D}$. Because the parent supplies funding, local lending by the affiliate is equal to the sum of:

$$
L_{i j} \equiv F_{i j}+D_{i j} .
$$

Following the Monti-Klein model, we assume a downward sloping demand for local loans by affiliates $L_{i j}$ and an upward sloping supply of parent funding $F_{i j}$ and local deposits $D_{i j}$ of foreign affiliates. As in Freixas and Rochet (2008), we also assume that foreign affiliates operate on local loan markets that are characterized by imperfect competition, thereby providing scope for earning a price margin. ${ }^{2}$ In contrast to complete foreign loan markets, foreign affiliates therefore set the amount of local lending $L_{i j}$ and parent funding $F_{i j}$, taking into account their influence on $R_{i j}^{L}$ and $R_{i j}^{F}$.

Through an internal capital market, foreign affiliates have access to parent funding $F_{i j}$, which may originate from multiple sources, such as deposits from other affiliates and wholesale funding. Empirically, we gauge the funding from German parents to their foreign affiliates. ${ }^{3}$ Resembling Park and Pennacchi (2009), we assume that foreign affiliates do not compete for local deposits in foreign markets if they have access to an internal capital market. Therefore, deposit rates $R_{i j}^{D}$ are exogenous and determine the amount of local deposits $D_{i j}$ in foreign markets. They can differ across foreign markets (Craig and Dinger, 2013).

To reflect our focus on local lending by the affiliate and parent funding, we use Equation (2) to substitute for $D_{i j}$ in Equation (1) and rewrite:

$$
\begin{aligned}
\pi_{i j} & =R_{i j}^{L} L_{i j}-R_{i j}^{F} F_{i j}-R_{i j}^{D}\left(L_{i j}-F_{i j}\right) \\
& =\underbrace{\left(R_{i j}^{L}-R_{i j}^{D}\right)}_{\text {price margin } \mathrm{M}^{\mathrm{p}}} L_{i j}+\underbrace{\left(R_{i j}^{D}-R_{i j}^{F}\right)}_{\text {funding cost margin } \mathrm{M}^{\mathrm{C}}} F_{i j} .
\end{aligned}
$$

2 Cross-country empirical evidence strongly suggest the existence of imperfect competition in banking markets (see e.g., Berger et al., 2004; Carbó et al., 2009).

3 See Frey and Kerl (2015) for an analysis of a "hub" function fulfilled by selected affiliates. 
Equation (3) highlights two intermediation margins. First, the price margin, $R_{i j}^{L}-R_{i j}^{D}$, is the difference between local lending and local deposit rates in foreign markets. Second, the funding cost margin, $R_{i j}^{D}-R_{i j}^{F}$, is the difference between local deposit rates in foreign markets and parent funding rates. This intermediation margin is consistent with the existence of an internal capital market in which foreign affiliates benefit from parent funding at a lower rate compared with the prevailing deposit rates in their foreign market.

We derive first-order conditions (FOCs) from Equation (3) as in Freixas and Rochet (2008). Foreign affiliates choose local lending $L_{i j}$ and parent funding, $F_{i j}$, conditional on their expected effect on $R_{i j}^{L}$ and $R_{i j}^{F}$. Note that this market structure implies that affiliates possess some market power, for instance because they cater to a specific niche of local credit markets (Berger et al., 2004; Carbó et al., 2009). They maximize profits at lower equilibrium lending levels $L_{i j}^{*}$ compared with the level under perfect competition, akin to credit rationing as in Stiglitz and Weiss (1981), and charge markup prices. Local deposits $D_{i j}$ depend on deposit rates in foreign markets $R_{i j}^{D}$. Using the inverse functions, $R_{i j}^{L}=R_{i j}^{L}\left(L_{i j}\right)$ and $R_{i j}^{F}=R_{i j}^{F}\left(F_{i j}\right)$, we rewrite Equation (3) as:

$$
\pi_{i j}=\pi_{i j}\left(L_{i j}, F_{i j}\right)=\left(R_{i j}^{L}\left(L_{i j}\right)-R_{i j}^{D}\right) L_{i j}+\left(R_{i j}^{D}-R_{i j}^{F}\left(F_{i j}\right)\right) F_{i j} .
$$

At parents that pursue decentralized internationalization strategies, affiliates might decide fairly autonomously about $L_{i j}$ and $F_{i j}$ (Nachum, 2003). But the empirical evidence in Cetorelli and Goldberg (2012b, 2012c) and Frey and Kerl (2015) suggests instead that international parents actively manage liquidity through internal capital markets, for instance by imposing or lifting internal funding constraints, or if treasury charges countryspecific refinancing costs on internal capital markets. To manage global lending, parents may also develop and deploy uniform loan approval rules or a common pricing model for all foreign affiliates. Such centralized managerial decision-making (see, e.g., Benston, Hanweck, and Humphrey, 1982) would force some foreign affiliates to lend less than their own profit-maximizing amount and others to lend more. Therefore, we assume that each parent $i$ chooses total local lending by the affiliates by considering the sum of foreign affiliate FOCs over $j=1, \ldots, n$. Total local lending by foreign affiliates then amounts to the following system of equations:

$$
\begin{gathered}
\frac{\partial \pi_{i 1}}{\partial L_{i 1}}=R_{i 1}^{\prime L}\left(L_{i 1}\right) L_{i 1}+R_{i 1}^{L}-R_{i 1}^{D}=0, \\
\vdots \\
\frac{\partial \pi_{i 1}}{\partial L_{i n}}=R_{i n}^{\prime L}\left(L_{i n}\right) L_{i n}+R_{i n}^{L}-R_{i n}^{D}=0 .
\end{gathered}
$$

If all individual foreign affiliates set their FOC equal to zero, lending by one foreign affiliate would not affect the lending by other foreign affiliates. But if the parent chooses the optimal amounts of local lending by the affiliate, this could imply positive FOCs for some foreign affiliates in the multinational network and negative FOCs elsewhere, while still satisfying the parent's overall lending FOC. When all foreign affiliate FOCs are not equal to zero, even though the overall parent FOC is, the optimal amount of local lending $L_{i j}^{*}$ of affiliate $j$ is no longer independent from the $L_{i j}^{*}$ of parent $i$ 's other foreign affiliates $j \neq m$. 
Therefore, we write the overall FOC of parent $i$ as the FOC of foreign affiliate $j$ plus the sum of FOCs of all its other foreign affiliates $j \neq m$ :

$$
\begin{gathered}
0=R_{i j}^{\prime L}\left(L_{i j}\right) L_{i j}+R_{i j}^{L}-R_{i j}^{D}+\sum_{i \neq m}^{n} R_{i j}^{\prime L}\left(L_{i j}\right) L_{i j}+R_{i j}^{L}-R_{i j}^{D} \\
L_{i j}^{*}=\frac{R_{i j}^{L}-R_{i j}^{D}}{-R_{i j}^{\prime L}}+\frac{1}{-R_{i j}^{\prime L}} \sum_{j \neq m}^{n} R_{i j}^{\prime} L L_{i j}^{*}+\frac{1}{-R_{i j}^{\prime L}} \sum_{j \neq m}^{n} R_{i j}^{L}-R_{i j}^{D} .
\end{gathered}
$$

The equilibrium condition in Equation (6) is useful to formulate expectations for our empirical tests. Consider first the effect of price margins of the affiliate itself, $R_{i j}^{L}-R_{i j}^{D}$ and recall that we assume a downward-sloping demand curve for local loans of the affiliate. Theoretically, foreign affiliates choose their local lending level $L_{i j}$ taking into account its effect on loan rates $R_{i j}^{L}$. This assumption of imperfect competition in loan markets implies that affiliates set loan quantities below perfect equilibrium quantities and realize larger price margins that maximize profits. The extent to which a contraction of local lending by affiliates increases price margins depends on the elasticity of local loan demand. ${ }^{4}$ We remain agnostic toward the level and cross-country heterogeneity of loan demand elasticities. Here, we merely argue that the ample evidence on pervasive market power in banking suggests that the inherent assumptions of the Monti-Klein model are appropriate. Empirically, we therefore expect a negative correlation between price margins and local lending by the affiliate. $^{5}$

Second, consider the effect of the local lending of all other affiliates $j \neq m$ of parent $i$ in their respective foreign markets. An expansion of local lending at given loan and deposit rates will require to allocate more parent funding to these markets since we assume that foreign affiliates do not compete for additional local deposits if internal capital markets are accessible. For given levels of local deposits $D_{i j}$ available to affiliate $j$, we therefore expect a lower level of equilibrium local lending in its foreign market.

Third, the effect of price margins of other affiliates within the parent is ambiguous. Since we assume that all other affiliates also operate on imperfect markets, an increase in price margins of other affiliates implies a contraction of local lending of these other affiliates $j \neq m$ and thus reduced total funding needs. Because foreign affiliates do not compete for local deposits, more parent funds are available to affiliate $j$. At given local deposit rates, and associated local deposit funding in affiliate $j$ 's market, this increase in parent funding can support an expansion of local lending, for example if rationed corporates in foreign markets $j \neq m$ borrow now from foreign affiliate $j .{ }^{6}$ A condition for such a positive relationship is that local lending by affiliate $j$ is a substitute for local loans of affiliates $j \neq m$. If this cross-border elasticity of substitution is in contrast low, we might observe no or even a

4 As reflected by, for example, the Lerner Index to gauge the competitive conditions in a market.

5 Note that this expectation is also reasonable under the assumption of complete loan markets. For an exogenous loan rate hike, foreign affiliates should be induced to supply more loans. However, the demand for local lending from foreign affiliates should decline. If we assume that the demand effect dominates, we would expect also without any market power among affiliates a negative correlation between price margins and local lending by the affiliate.

6 Note that we observe empirically only local lending by affiliate $j$ to customers in market $j$. But even then multinational corporations on the borrower side of credit markets might shift demand from their subsidiaries $j \neq m$ to market $j$ in search for credit. 
negative correlation between price margins of other affiliates and affiliate $j$ 's equilibrium level of local lending. Therefore, this effect remains ultimately an empirical question.

Next we consider the system of FOCs for funding. For each parent $i$ the FOCs of its affiliates $j=1, \ldots, n$ with respect to funding are defined as:

$$
\begin{gathered}
\frac{\partial \pi_{i 1}}{\partial F_{i 1}}=-R_{i 1}^{\prime F}\left(F_{i 1}\right) F_{i 1}+R_{i 1}^{D}-R_{i 1}^{F}=0 \\
\vdots \\
\frac{\partial \pi_{i 1}}{\partial F_{i n}}=-R_{i n}^{\prime F}\left(F_{i n}\right) F_{i n}+R_{i n}^{D}-R_{i n}^{F}=0 .
\end{gathered}
$$

Parents may use uniform funding allocation rules that maximize their overall funding FOC, but not necessarily that of individual foreign affiliates. More generally, an efficient internal capital market implies to optimize the amount of funding at the parent instead of at the affiliate level, such that the funding of affiliate $j$ and affiliates $j \neq m$ depend on each other. Therefore, we decompose the parent's FOC into a part for affiliate $j$ and a part for all other affiliates $j \neq m$.

$$
\begin{aligned}
0 & =-R_{i j}^{\prime F}\left(F_{i j}\right) F_{i j}+R_{i j}^{D}-R_{i j}^{F}-\sum_{j \neq m}^{n} R_{i j}^{\prime F}\left(F_{i j}\right) F_{i j}+R_{i j}^{D}-R_{i j}^{F} \\
F_{i j}^{*} & =\frac{R_{i j}^{D}-R_{i j}^{F}}{R_{i j}^{\prime F}}+\frac{1}{R_{i j}^{\prime F}} \sum_{j \neq m}^{n} R_{i j}^{\prime F} F_{i j}+\frac{1}{R_{i j}^{\prime F}} \sum_{j \neq m}^{n} R_{i j}^{D}-R_{i j}^{F} .
\end{aligned}
$$

Larger relative funding cost advantages of parents relative to the cost of local deposits in a foreign market correspond with larger funding cost margins. If globally optimizing parents allocate more funding through internal capital markets to such individual affiliates, we expect a positive effect of funding cost margins on parent funding volumes.

The effect of parent funding volumes being routed to other affiliates should reduce the available amount of parent funding for affiliate $j$. At given local deposit rates, we therefore expect a negative effect of the parent funding volume of foreign affiliates $j \neq m$ on the parent funding received by affiliate $j$.

Contrary to the ambiguous effect of price margins of other affiliates on local lending, we expect a negative effect of funding cost margins of other affiliates of parent $i$. The reason is that we assume that foreign affiliates do not compete for local deposits for as long as internal capital market funding is available. So whereas the effect of local lending by affiliate $j$ depends on credit market conditions in foreign markets, an increase in the relative cost of local deposit funding should ceteris paribus induce parents to substitute local deposit funding with relatively cheaper parent funds. Therefore, if the funding cost margins of other affiliates increase, parents are likely to fund these affiliates more at the expense of affiliate $j$.

\subsection{Methodology}

The data feature parents $i$ with foreign affiliates $j$ in country $k$ at year $t$, which calls for a three-dimensional ijt panel where foreign affiliates are nested in countries. Because in theory parents optimize the allocation of lending and funding across their foreign affiliates, we specify next to affiliate- and country-level controls parent $\times$ year fixed effects. Hence, we explain within parent-year variation across foreign affiliates. Country fixed effects gauge 
time-invariant, unobserved country differences. To mitigate simultaneity concerns, we lag all explanatory variables and estimate Equations (6) and (8) as follows:

$$
\begin{aligned}
L_{i j k t}= & \alpha^{L}+\beta_{1}^{L} M_{k t-1}^{P}+\beta_{2}^{L} M_{i k t-1}^{P, \text { Oth. }}+\beta_{3}^{L} L_{i k t-1}^{\text {Oth. }} \\
& +\gamma^{L} \text { Controls }_{j k t-1}+\delta_{i t}^{L}+\delta_{k}^{L}+\epsilon_{i j k t}^{L}, \text { and } \\
F_{i j k t}= & \alpha^{F}+\beta_{1}^{F} M_{i k t-1}^{C}+\beta_{2}^{F} M_{i k t-1}^{C, \text { Oth. }}+\beta_{3}^{F} F_{i k t-1}^{\text {Oth. }} \\
& +\gamma^{F} \text { Controls }_{j k t-1}+\delta_{i t}^{F}+\delta_{k}^{F}+\epsilon_{i j k t}^{F},
\end{aligned}
$$

where $L_{i j k t}$ is the volume of local lending by the affiliate. $F_{i j k t}$ denotes net parent funding, which equals the liabilities of foreign affiliates vis-à-vis their parents less the assets vis-à-vis their parents. $M_{k t-1}^{P}$ is the price margin and $M_{i k t-1}^{C}$ is the funding cost margin.

Theory suggests to specify margins, local loans, and parent funding by each other affiliate of parent $i$ as separate explanatory variables of affiliate $j$ 's local lending and parent funding. Empirically, we face the challenge that such a model is overfitted and suffers from the curse of dimensionality, that is not each parent $i$ in our sample operates the same number of affiliates $j$. Therefore, we use country-weighted averages of aggregate local lending of the other affiliates. Equation (9) therefore also contains for each parent-year combination the country-weighted averages of both the price margin $M_{i k t-1}^{p \text {,Oth. }}$ and the local lending $L_{i k t-1}^{\text {Oth. }}$ of parent $i$ 's other affiliates $j \neq m$, henceforth Price margins of other affiliates and Local lending of other affiliates, respectively. ${ }^{7}$ Equation (10) contains for each parent-year combination the country-weighted averages of both the funding cost margin $M_{i k t-1}^{C, \text { Oth. }}$ and the funding $F_{i k t-1}^{\mathrm{Oth}}$ of parent $i$ 's other foreign affiliates $j \neq m$, henceforth Funding cost margins of other affiliates and Parent funding of other affiliates, respectively. The vector controls $_{j k t-1}$ consists of foreign country controls $X_{k t-1}$ and foreign affiliate controls $X_{j t-1}$. $\delta_{i t}$ is a vector of the parent $\times$ year fixed effects and $\delta_{k}$ is a vector of foreign country fixed effects. We discuss the summary statistics and sources next.

\section{Data}

\subsection{Sampling}

We obtain data about the international assets of German parents' branches and subsidiaries, or foreign affiliates for short, from the External Position Report of Deutsche Bundesbank. We augment these data with financial account information reported to Bundesbank by all universal banks, that is, commercial, savings, and cooperatives, during the period 2003-07. This time period reflects our focus on explaining the interaction between parent funding and the local lending by the affiliate during tranquil times with our theoretical model.

The raw sample contains 92 unique parents with foreign lending through 507 affiliates. Due to (minor) attrition and missing data for control variables, we retain 71 parents and 417 affiliates in the preferred lending estimation sample and 66 parents and 406 affiliates in the preferred funding estimation sample. ${ }^{8}$ These parents are identical to those in Buch, Koch, and Koetter (2011b). Hence, we capture all large international players and accurately describe internationalization patterns of German parents.

7 Note that the reason $M_{i k t-1}^{P \text {,oth. }}$ also varies over parents $i$, whereas $M_{k t-1}^{P}$ does not, is that each parent has a different combination of other affiliate countries to which it is lending.

8 The numbers correspond to the specifications in Column (3) of panels A and B in Table III. 
A first distinctive advantage of the sample is that we observe the net funding positions between all parents in Germany's banking system to all of their foreign affiliates. Such internal capital market data paired with detailed balance sheet information of foreign affiliates that contain also the geographic origin and the destination of funds is rare. As a second important advantage, these data are available at the affiliate-level for both branches and subsidiaries. Most studies only observe legally independent, separately chartered subsidiaries, which are obliged to report financial statements, whereas foreign branches are not (Frey and Kerl, 2015). Neglecting foreign branches inflicts a potentially severe bias since they are an important channel of multinational banking. For German parents, they are more numerous than subsidiaries and account for approximately twice the volume of local lending routed through subsidiaries (Buch, Koch, and Koetter, 2011b; Frey and Kerl, 2015).

At the same time, two limitations warrant mentioning. First, ideally we would observe the (average) lending and deposit rates of each individual affiliate to measure interest margins. Unfortunately, neither foreign affiliates nor parents report interest rates in general. Foreign affiliates do also not report profit and loss accounts, which would permit to impute interest rates. One alternative is then to match affiliates to the Bankscope database using the foreign bank database of Claessens and van Horen (2014a, 2014b). That approach would suffer from the aforementioned bias to neglect foreign branches, which are not covered by Bankscope. We choose for the lesser of two evils and measure interest rates and the according margins at the country level. This approach is also consistent with our model where parents choose local lending and parent funding quantities given rates in incomplete foreign markets. A second limitation concerns internal capital market flows between parents and branches. For our sample period, only subsidiaries directly report internal capital market exposures to their parents. Branches only began reporting this position as of June 2010. But they report the geographical source of aggregate funding on a country-by-country basis, including Germany. Like Frey and Kerl (2015), we assume that the funding exposure of affiliate $j$ to Germany equals the exposure to their parent, such that foreign branches borrow in their domestic market (Germany) only from their parent. Comparing aggregate German funding and borrowing from parents by branches after June 2010 confirms a near-complete overlap.

Buch, Koch, and Koetter (2011b) report that out of all banks with a German banking charter only few banks operate foreign affiliates, of which most are part of only the largest, truly global parents. Therefore, we distinguish banks in any given year without any affiliate at all (Domestic) from those parents that do have a number of affiliates below the median number of affiliates (International) and those parents, which operate a number of affiliates above the median (Global). Conditional on a positive number of affiliates (i.e., the group of International and Global parents), the median number of affiliates is 25 in 2003, 23 in each year 2004-06, and 14 in 2007.

The last column of Table I (All) shows that there are five global and seventy-four international parents that are at some stage active in local lending by the affiliate, parent funding, or both compared with 2,158 domestic banks. International and global parents have affiliates in fifty-eight countries (Table AI). The number of international and especially domestic banks declines over time significantly, illustrating the intensive consolidation of the German banking sector during the sample period.

Table I also shows that global parents are active in approximately five times as many countries as are international parents. The average number of countries served by global parents is twenty-nine compared with slightly less than six countries, in which international parents operate affiliates. Likewise, global parents operate around five times more affiliates 
Table I. International activities of parents and foreign affiliates

This table reports summary statistics for the raw sample year-by-year and across the sample period 2003-07 (column All). Parents are categorized into three groups according to the distribution of their number of affiliates. Global indicates parents with an above median number of affiliates, International indicates parents with a below median but positive number of affiliates, and Domestic indicates parents with no affiliates. Number of parents indicates the number of parents in each year and group. For each year and group we average the number of countries and affiliates over the Number of parents to create Average number of countries and Average number of affiliates, respectively. Aggregate local lending by affiliates is the sum of local lending across all affiliates per parent in a given year. Aggregate parent funding is the sum of parent funding received by all affiliates per parent in a given year. For both variables we show the mean across parents in billions of Euros.

\begin{tabular}{llrrrrrr}
\hline Variable & Group & 2003 & 2004 & 2005 & 2006 & 2007 & All \\
\hline Number of parents & Global & \multicolumn{1}{c}{4} & \multicolumn{1}{c}{4} & \multicolumn{1}{c}{4} & 4 & 5 & \multicolumn{1}{c}{5} \\
& International & \multicolumn{1}{l}{65} & \multicolumn{1}{c}{61} & 60 & \multicolumn{1}{c}{57} & \multicolumn{1}{c}{54} & \multicolumn{1}{c}{74} \\
& Domestic & 1,986 & 1,912 & 1,845 & 1,803 & 1,765 & 2,158 \\
Average number of countries & Global & 30.58 & 29.43 & 29.58 & 29.13 & 25.99 & 28.94 \\
& International & 6.16 & 6.15 & 6.22 & 5.99 & 4.60 & 5.87 \\
Average number of affiliates & Global & 49.65 & 46.78 & 45.38 & 44.27 & 35.59 & 44.33 \\
& International & 7.72 & 7.66 & 7.63 & 7.26 & 5.37 & 7.19 \\
Aggregate local lending by affiliates & Global & 67.52 & 63.08 & 68.74 & 72.43 & 63.40 & 66.99 \\
& International & 8.26 & 7.35 & 7.03 & 8.02 & 3.98 & 7.03 \\
Aggregate parent funding & Global & 1.03 & -1.35 & 4.98 & 1.57 & 7.12 & 2.68 \\
& International & 1.82 & 2.55 & 3.59 & 4.25 & 2.28 & 2.90 \\
\hline
\end{tabular}

than international parents. We also aggregate local lending by all affiliates of each parent in a given year. The shown average of the Aggregate local lending by affiliates is around ten times larger for global parents compared with international parents. Likewise, the mean of Aggregate parent funding equals the sum of all parent funding received by foreign affiliates of a given parent. It is, in turn, much smaller as we are measuring net positions of the parent vis-à-vis its affiliates. Whereas it is fairly comparable for global and international parents, note that the average global parent received financial funds from their affiliate networks in the year 2004, which supports the notion of actively managed internal capital markets.

Figure 1 shows two histograms: one of the number of affiliates (top) and one of the number of countries with affiliate presence (bottom), both for each parent in each year. They show that around half of all internationally active parents operate just one foreign affiliate and are present in just one foreign market in any given year. The top histogram shows that the fraction of parents that are active with more than five foreign affiliates is less than a fifth of the sample. Likewise, the bottom one shows that in only $20 \%$ of the parent-years we observe affiliate presence in more than three foreign markets. These descriptive statistics on foreign presence though affiliates underscore that only very few German parents are truly global: an unreported tabulation shows that in only $6.6 \%$ of the parentyears the number of affiliates is larger than the median number of affiliates reported above. Since both the business and the funding models pursued by international and global parents may differ, we investigate the interaction between local lending by affiliates and internal capital market funding through international and global parents in more depth below. 

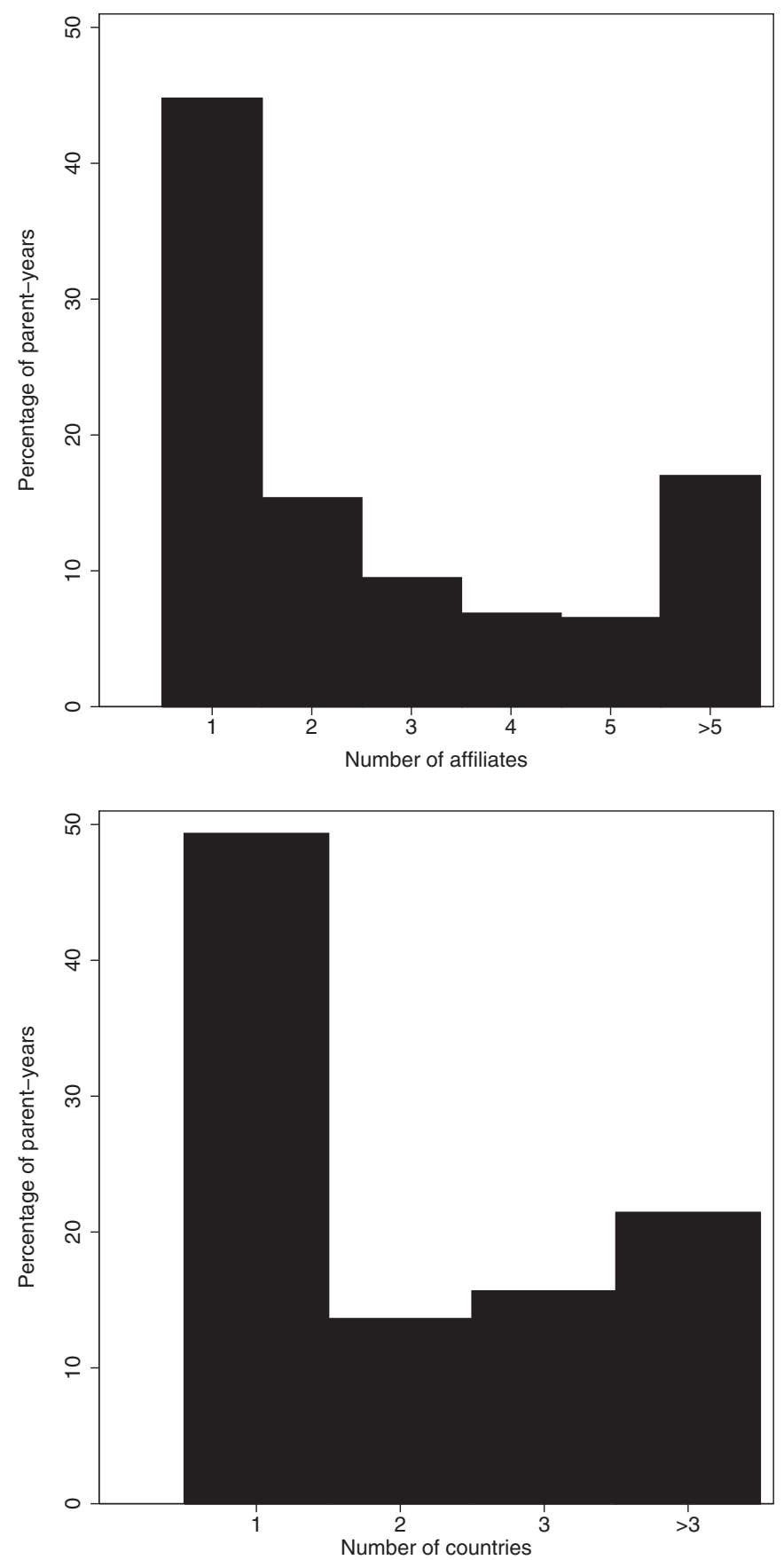

Figure 1. This figure shows two discrete histograms: a histogram of the number of affiliates (top) and a histogram of the number of countries with affiliate presence (bottom), both for each parent in each year. The $y$-axis reports the percentage of parent-years instead of the density and for confidentiality reasons the extreme discrete bins are grouped together. Both histograms are based on our lending sample (Column (3) of Table III). 
Table II. Summary statistics parent-affiliate-year sample

This table reports summary statistics for the regression samples in Column 3 of Table III. Table All provides the variable definitions.

\begin{tabular}{|c|c|c|c|c|c|}
\hline & Mean & SD & $\mathrm{p} 5$ & p95 & $\mathrm{N}$ \\
\hline \multicolumn{6}{|l|}{ Panel A: Local lending by affiliates sample } \\
\hline Local lending by the affiliate & 1.065 & 3.614 & 0.000 & 4.421 & 1,602 \\
\hline Price margin & 8.480 & 7.143 & 1.778 & 21.601 & 1,602 \\
\hline Lending rate & 11.966 & 8.287 & 3.586 & 27.297 & 1,602 \\
\hline Deposit rate & 3.360 & 2.540 & 1.194 & 6.600 & 1,602 \\
\hline Price margins of other affiliates & 7.651 & 5.167 & 0.000 & 17.764 & 1,602 \\
\hline Local lending of other affiliates & 2.457 & 3.623 & 0.000 & 11.039 & 1,602 \\
\hline Aff. Equity ratio & 8.984 & 16.745 & 0.000 & 41.436 & 1,602 \\
\hline Aff. Liquidity & 1.568 & 5.193 & 0.000 & 6.665 & 1,602 \\
\hline Aff. Wholesale funding & 7.217 & 16.889 & 0.000 & 45.114 & 1,602 \\
\hline $\ln$ (Aff. Total assets) & 13.689 & 2.315 & 9.422 & 17.071 & 1,602 \\
\hline Affiliate $=$ subsidiary & 0.548 & 0.498 & 0.000 & 1.000 & 1,602 \\
\hline Credit to GDP & 111.602 & 46.532 & 28.070 & 181.202 & 1,602 \\
\hline Foreign owned banks & 44.292 & 31.454 & 5.051 & 97.368 & 1,602 \\
\hline GDP per capita & 35.345 & 21.526 & 3.758 & 78.072 & 1,602 \\
\hline Distance & 2.777 & 3.830 & 0.197 & 10.380 & 1,602 \\
\hline Activity restrictions & 5.490 & 1.804 & 3.000 & 9.000 & 1,560 \\
\hline Capital regulations & 5.379 & 1.566 & 3.000 & 8.000 & 1,560 \\
\hline \multicolumn{6}{|l|}{ Panel B: Parent funding sample } \\
\hline Parent funding & 0.167 & 1.802 & -1.879 & 2.333 & 1,543 \\
\hline Funding cost margin & 0.153 & 2.902 & -3.210 & 3.728 & 1,543 \\
\hline Parent funding rate & 3.235 & 1.286 & 1.828 & 4.479 & 1,543 \\
\hline Deposit rate & 3.368 & 2.580 & 1.194 & 6.600 & 1,543 \\
\hline Funding cost margins of other affiliates & 1.909 & 5.256 & -1.928 & 15.641 & 1,543 \\
\hline Parent funding of other affiliates & -0.023 & 1.161 & -1.949 & 1.743 & 1,543 \\
\hline Aff. Equity ratio & 9.183 & 17.012 & 0.000 & 42.551 & 1,543 \\
\hline Aff. Liquidity & 1.597 & 5.267 & 0.000 & 6.665 & 1,543 \\
\hline Aff. Wholesale funding & 7.343 & 17.026 & 0.000 & 45.166 & 1,543 \\
\hline $\ln$ (Aff. Total assets) & 13.724 & 2.306 & 9.474 & 17.104 & 1,543 \\
\hline Affiliate $=$ subsidiary & 0.543 & 0.498 & 0.000 & 1.000 & 1,543 \\
\hline Credit to GDP & 111.905 & 46.938 & 27.508 & 181.202 & 1,543 \\
\hline Foreign owned banks & 44.352 & 31.179 & 5.051 & 97.368 & 1,543 \\
\hline GDP per capita & 35.008 & 21.409 & 3.490 & 78.072 & 1,543 \\
\hline Distance & 2.855 & 3.880 & 0.197 & 10.380 & 1,543 \\
\hline Activity restrictions & 5.512 & 1.803 & 3.000 & 9.000 & 1,501 \\
\hline Capital regulations & 5.380 & 1.570 & 3.000 & 8.000 & 1,501 \\
\hline
\end{tabular}

\subsection{Local Lending By Affiliates, Parent Funding, and Margins}

The dependent variable in Equation (9), $L_{i j k t}$, is end-of-year stocks of local loans by affiliates to non-financial firms and households in foreign market $k$, measured in billions of Euros. The variables are defined in Table AII. Table II contains the summary statistics. ${ }^{9}$

9 Table OA1 in the Online Appendix shows summary statistics for global and international parents. Table OA5 in the Online Appendix also specifies alternative dependent variables: the logs of local 
We only include local lending by the affiliate $j$ in foreign market $k$ itself and exclude onward lending (see Frey and Kerl, 2015), interbank, or government lending. Thereby, the interest margins derived at the country level, where foreign affiliates are located, correspond to the lending choices that we observe in the host country of the affiliate.

The dependent variable in Equation (10) is net parent funding of foreign affiliate $j$ received through the internal capital markets of parent $i$. The specification of net parent funding permits for the possibility that some affiliates in some countries act as suppliers of funding to parents, akin to core funding countries identified in Cetorelli and Goldberg (2012b). To obtain data for the volume of funding $F_{i j k t}$ held by foreign affiliates from their parents, we follow Frey and Kerl (2015) and measure parent funding as the difference between affiliate liabilities toward the parent less assets vis-à-vis the parent.

The two main test variables that follow from the theoretical model are the price margin and the funding cost margin. The price margin $M_{k t-1}^{P}$ is the difference between local lending and deposit rates in foreign markets: $M_{k t-1}^{P}=R_{k t-1}^{L}-R_{k t-1}^{D}$. We use parent-level Bankscope financial accounts data for each foreign market $k$ and year $t$ to generate $R_{k t-1}^{L}$ as the country-year median of (lagged) total interest income over gross loans. When the data needed to generate these variables are missing, we augment it with lending and deposit rates from the World Development Indicators (WDIs) provided by the World Bank. ${ }^{10}$

Deposit rates $R_{k t-1}^{D}$ are defined as the country-year median of (lagged) total interest expense over total deposits. The funding cost margin is defined as $M_{i k t-1}^{C}=R_{k t-1}^{D}-R_{i t-1}^{F}$. Parent funding rates $R_{i t-1}^{F}$ equal the average funding costs of the German parent $i$, defined as interest expenses divided by interest-bearing liabilities. These financial accounts data come from unconsolidated financial statements reported by all parents to the Bundesbank.

The margins, local lending, and parent funding of other affiliates are calculated as weighted averages based on two alternative weighting schemes. Our preferred weighting scheme consists of using the inverse distances from foreign affiliate $j$ 's country to the countries of other foreign affiliates $j \neq m$ as weights to reflect that geographically closer markets are more likely to affect each other in terms of market shares and pricing. Distance is used in many financial (e.g., Degryse and Ongena, 2005), and international trade studies (e.g., Yeaple, 2009), to proxy "transportation" costs. In our context of international banking, such costs capture information frictions that increase the costs to generate private information in lending relationships. As a robustness check we also use the correlation of business cycles across markets, because parents may manage foreign affiliates like a portfolio, seeking to reduce correlated (macro) risks (Aviat and Coeurdacier, 2007; Buch, Koch, and Koetter, 2014). We use the preceding 5-year GDP growth rate correlation between the country of affiliate $j$ and the countries of other affiliates $j \neq m$. Both approaches imply that the effect of other foreign affiliates' local lending and price margins is stronger when they are located closer to affiliate $j$ or if foreign affiliates' markets exhibit a more synchronous business cycle.

Table II shows the margins, local lending, and parent funding of other affiliates, which correspond to the weighting scheme using the inverse of the geographic distance between

lending by the affiliate and parent funding, total assets of affiliates, and local lending scaled by total assets of the affiliate. Main results remain unaffected.

10 Table OA5 in the Online Appendix shows that the results are qualitatively robust to choosing just one source, the use of mean interest rates, and alternative outlier treatments. 
foreign affiliate $j$ and its parent. Table OA2 in the Online Appendix shows very similar results when using the GDP growth rate correlation weighting scheme instead. These estimates are less precise because most observations in the sample pertain to countries that exhibit very similar business cycles (Table AI), thereby absorbing much of the variation of interest in weighted margins.

\subsection{Control Variables}

We include foreign affiliate variables $X_{j t-1}$ that are inspired by Buch, Koch, and Koetter (2011a) and Cetorelli and Goldberg (2012b, 2012c) to control for affiliate-level variation within parent-years in Equations (9) and (10). First, we specify the Aff. Equity ratio as the ratio of equity to assets to control for risk-return considerations that are driving local lending and parent funding choices. Second, we specify Aff. Liquidity equal to cash and vault cash with central banks over total assets. This variable controls for the dependence of foreign affiliates on local and parent funding to support their local lending. Third, we specify Aff. Wholesale funding as the ratio of securitized debt to total liabilities. This refinancing strategy might be cheaper, but also bears more exposure to lumpy funding withdrawals (Craig and Dinger, 2013). Parent traits are captured by the parent $\times$ year fixed effects. ${ }^{11}$ Fourth, we include the natural logarithm of total assets, $\ln$ (Aff. Total assets), because the dependent variables are measured as absolute volumes of local lending by the affiliate and net parent funding. These volumes depend on affiliate size. Finally, we specify an indicator variable equal to 1 if the affiliate is a subsidiary chartered in market $k$ and 0 if it is a foreign branch.

Next, we include time-variant, country-specific controls $X_{k t-1}$ to gauge factors that influence local lending by the affiliate and parent funding. We include Credit to GDP, which is the ratio of domestic credit provided by the private sector to GDP. We account for differences in competition from other foreign banks, which is likely to affect interest margins: Foreign owned banks is the percentage of foreign banks active in each foreign market $k$ as reported in the bank ownership database of Claessens and van Horen (2014a). Finally, we include GDP per capita in constant 2005 US dollars from the WDI to control for credit market size differentials abroad.

As an alternative to country fixed effects, we include time-invariant country traits that may drive local lending by the affiliate. The first is Distance, measured as the physical distance between the foreign market and Germany (CEPII, Paris). We obtain Activity restrictions and Capital regulations indicators from the 2003 vintage of the Barth, Caprio, and Levine (2001) database to gauge regulatory conditions at the beginning of our sample period. ${ }^{12}$ Activity restrictions indicate whether banks are restricted from engaging in securities underwriting, insurance underwriting and selling, real estate investments, management, and development. Higher scores indicate more stringency and restrictions. Capital regulations is a combined measure of overall and initial capital stringency. Since these controls can only be specified instead of country fixed effects, we do not specify them in our preferred specification.

11 Alternatively, Table OA3 in the Online Appendix specifies observed parent traits and fixed effects for parents, countries, and years. Results are qualitatively unaffected.

12 These variables are not per se time-invariant but measured at one point in time when the survey was conducted. 


\section{Results}

\subsection{Main Results}

Table III shows the baseline results for Equation (9) that explains local lending by the affiliate in the upper panel A and the parent funding Equation (10) in panel B. We cluster standard errors at the parent-year level throughout.

\section{1.a. Local lending by the affiliate}

Parents may differ systematically in their ability and willingness to lend abroad through affiliates, as suggested by the evidence of active internal capital market management in Cetorelli and Goldberg (2012b, 2012c). In the parsimonious specification in Column (1), we control for these differences with the parent $\times$ year fixed effects. The main variable of interest is the price margin. The estimation results confirm the first theoretical prediction of a negative relationship with local lending by the affiliate, although only at the $10 \%$ level of confidence. This effect is consistent with the monopolistic competition assumption in the theoretical model, but also with credit rationing à la Stiglitz-Weiss. The results in Column (1) identify the effects of local lending by the affiliate solely on the basis of parent $\times$ year fixed effects, country-fixed effects, and differences within the parent across foreign affiliates in terms of lending and price margins. A one standard deviation increase equals 7.1 percentage points (Table II), which indicates a decline in lending on the order of 213 million Euros for the estimated coefficient of -0.0298 . This magnitude equals $20 \%$ of mean foreign local lending by the affiliate of 1.065 billion Euros (Table II). ${ }^{13}$

The individual effect of affiliates' price margins on their local lending shown in Column (1) is robust to the inclusion of observed local lending and price margins of other affiliates within the parent. Local lending of other affiliates of the parent reduces an affiliate's own local lending. This negative effect confirms our expectation that the associated need for additional parent funding among the parent's other foreign affiliates $j \neq m$ implies a reduction of local lending by affiliate $j$.

Recall that the effect of higher price margins of other affiliates on local lending by the affiliate was ambiguous. For this sample, we estimate a negative effect that is statistically significant. Therefore, local lending by affiliate $j$ does not appear to be a substitute for local loans of affiliates $j \neq m$. As discussed in Section 2.1, any potentially freed up parent funding at other affiliates that is commensurate with reduced local lending due to reduced price margins in their markets does not imply an expansion of local lending by affiliate $j$.

Differences in local lending across affiliates may also reflect affiliate-specific traits other than price margins. We account in Column (2) for affiliate-level lending determinants in foreign markets. Larger capital buffers increase the loan generating capacity of foreign affiliates significantly. Our point estimates indicate that an increase in book equity relative to gross total assets by 1 percentage point increases local loans of affiliates by 45 million Euros.

Liquidity differences across affiliates are not statistically correlated with local lending by the affiliate in our sample. This absence of a relationship is somewhat at odds with the evidence on sudden stops of cross-border lending in response to the financial crisis, see for example Popov and Udell (2012) or De Haas and Van Horen (2013). The result is 
Table III. Main estimates

This table reports estimates of Equation (9) in panel A and estimates of Equation (10) in panel B for the years 2003-07. All explanatory variables are lagged by one period. Margins and volumes of other affiliates are country-weighted averages of all other affiliates per parent, using the inverse of geographical distance as weight. Standard errors are clustered at the parent-year level and are reported in parentheses and $*^{* *},{ }^{*}$, and ${ }^{*}$ correspond to the $1 \%, 5 \%$, and $10 \%$ level of significance, respectively. All estimations feature parent $\times$ year FE and country-fixed effects, except those in Column (4) in which there are only parent $\times$ year FE.

\begin{tabular}{|c|c|c|c|c|}
\hline Panel A: Local lending by affiliate & $(1)$ & $(2)$ & (3) & (4) \\
\hline Price margin & $\begin{array}{r}-0.0273 * \\
(0.0148)\end{array}$ & $\begin{array}{c}-0.0298 * * \\
(0.0138)\end{array}$ & $\begin{array}{c}-0.0301 * * \\
(0.0136)\end{array}$ & $\begin{array}{c}-0.0367 * * \\
(0.0126)\end{array}$ \\
\hline Price margins of other affiliates & $\begin{array}{c}-0.1107 * * \\
(0.0308)\end{array}$ & $\begin{array}{c}-0.1338 * * * \\
(0.0352)\end{array}$ & $\begin{array}{c}-0.1353 * * * \\
(0.0343)\end{array}$ & $\begin{array}{c}-0.1338 * * * \\
(0.0297)\end{array}$ \\
\hline Local lending of other affiliates & $\begin{array}{c}-0.3206 * * * \\
(0.0212)\end{array}$ & $\begin{array}{c}-0.3157 * * * \\
(0.0356)\end{array}$ & $\begin{array}{c}-0.3156 * * \\
(0.0355)\end{array}$ & $\begin{array}{c}-0.2707 * * \\
(0.0228)\end{array}$ \\
\hline Aff. Equity ratio & & $\begin{array}{l}0.0447 * * * \\
(0.0075)\end{array}$ & $\begin{array}{l}0.0448 * * * \\
(0.0075)\end{array}$ & $\begin{array}{l}0.0363 * * * \\
(0.0056)\end{array}$ \\
\hline Aff. Liquidity & & $\begin{array}{r}-0.0115 \\
(0.0082)\end{array}$ & $\begin{array}{r}-0.0111 \\
(0.0082)\end{array}$ & $\begin{array}{r}-0.0118 \\
(0.0119)\end{array}$ \\
\hline Aff. Wholesale funding & & $\begin{array}{c}-0.0118 * * * \\
(0.0031)\end{array}$ & $\begin{array}{c}-0.0117 * * * \\
(0.0031)\end{array}$ & $\begin{array}{r}-0.0028 \\
(0.0026)\end{array}$ \\
\hline $\ln$ (Aff. Total assets) & & $\begin{array}{l}1.2050 * * * \\
(0.1383)\end{array}$ & $\begin{array}{l}1.2050 * * * \\
(0.1385)\end{array}$ & $\begin{array}{l}1.0136^{* * *} \\
(0.1055)\end{array}$ \\
\hline Affiliate $=$ subsidiary & & $\begin{array}{l}1.1344 * * * \\
(0.2766)\end{array}$ & $\begin{array}{l}1.1340 * * * \\
(0.2772)\end{array}$ & $\begin{array}{l}1.0532 * * * \\
(0.2049)\end{array}$ \\
\hline Credit to GDP & & & $\begin{array}{c}0.0031 \\
(0.0117)\end{array}$ & $\begin{array}{l}0.0081 * * * \\
(0.0022)\end{array}$ \\
\hline Foreign owned banks & & & $\begin{array}{r}-0.0065 \\
(0.0265)\end{array}$ & $\begin{array}{c}-0.0072 * * * \\
(0.0023)\end{array}$ \\
\hline GDP per capita & & & $\begin{array}{c}0.0229 \\
(0.0766)\end{array}$ & $\begin{array}{c}-0.0208 * * \\
(0.0048)\end{array}$ \\
\hline Distance & & & & $\begin{array}{c}-0.1944 * * * \\
(0.0252)\end{array}$ \\
\hline Activity restrictions & & & & $\begin{array}{l}0.2834 * * * \\
(0.0516)\end{array}$ \\
\hline Capital regulations & & & & $\begin{array}{c}0.0465 \\
(0.0373)\end{array}$ \\
\hline Observations & 1,647 & 1,610 & 1,602 & 1,560 \\
\hline$R$-squared & 0.195 & 0.393 & 0.392 & 0.325 \\
\hline Number of parents & 76 & 72 & 71 & 71 \\
\hline Number of affiliates & 429 & 420 & 417 & 408 \\
\hline Number of foreign markets & 58 & 58 & 55 & 52 \\
\hline Panel B: Parent funding & (1) & (2) & (3) & (4) \\
\hline Funding cost margin & $\begin{array}{c}0.0117 \\
(0.0214)\end{array}$ & $\begin{array}{c}0.0095 \\
(0.0212)\end{array}$ & $\begin{array}{c}0.0389 \\
(0.0241)\end{array}$ & $\begin{array}{c}0.0097 \\
(0.0120)\end{array}$ \\
\hline $\begin{array}{l}\text { Funding cost margins of other } \\
\text { affiliates }\end{array}$ & $\begin{array}{c}0.0363 \\
(0.0232)\end{array}$ & $\begin{array}{c}0.0336 \\
(0.0246)\end{array}$ & $\begin{array}{l}0.0456 * \\
(0.0241)\end{array}$ & $\begin{array}{l}0.0259 * \\
(0.0143)\end{array}$ \\
\hline
\end{tabular}


Table III. Continued

\begin{tabular}{|c|c|c|c|c|}
\hline Panel B: Parent funding & (1) & (2) & (3) & (4) \\
\hline Parent funding of other affiliates & $\begin{array}{l}-0.8782^{* * *} \\
(0.0636)\end{array}$ & $\begin{array}{l}-0.8628^{* * *} \\
(0.0585)\end{array}$ & $\begin{array}{c}-0.8660^{* * *} \\
(0.0579)\end{array}$ & $\begin{array}{c}-0.8633^{* * *} \\
(0.0563)\end{array}$ \\
\hline Aff. Equity ratio & & $\begin{array}{c}0.0035 \\
(0.0030)\end{array}$ & $\begin{array}{c}0.0033 \\
(0.0030)\end{array}$ & $\begin{array}{l}0.0060^{* *} \\
(0.0024)\end{array}$ \\
\hline Aff. Liquidity & & $\begin{array}{r}-0.0006 \\
(0.0081)\end{array}$ & $\begin{array}{c}-0.0005 \\
(0.0083)\end{array}$ & $\begin{array}{c}0.0078 \\
(0.0065)\end{array}$ \\
\hline Aff. Wholesale funding & & $\begin{array}{l}-0.0161^{* * *} \\
(0.0036)\end{array}$ & $\begin{array}{l}-0.0160 * * * \\
(0.0035)\end{array}$ & $\begin{array}{c}-0.0163 * * \\
(0.0035)\end{array}$ \\
\hline $\ln$ (Aff. Total assets) & & $\begin{array}{l}0.1649 * * * \\
(0.0419)\end{array}$ & $\begin{array}{l}0.1633^{* * *} \\
(0.0418)\end{array}$ & $\begin{array}{l}0.1641 \\
(0.0349)\end{array}$ \\
\hline Affiliate $=$ subsidiary & & $\begin{array}{c}0.1947^{*} \\
(0.1073)\end{array}$ & $\begin{array}{c}0.1981^{*} \\
(0.1074)\end{array}$ & $\begin{array}{l}0.2736^{* * *} \\
(0.0979)\end{array}$ \\
\hline Credit to GDP & & & $\begin{array}{c}0.0101 \\
(0.0063)\end{array}$ & $\begin{array}{l}0.0034 * * \\
(0.0014)\end{array}$ \\
\hline Foreign owned banks & & & $\begin{array}{c}0.0123 \\
(0.0195)\end{array}$ & $\begin{array}{c}-0.0065^{* * *} \\
(0.0013)\end{array}$ \\
\hline GDP per capita & & & $\begin{array}{r}-0.0880 \\
(0.0633)\end{array}$ & $\begin{array}{c}-0.0106^{* *} \\
(0.0051)\end{array}$ \\
\hline Distance & & & & $\begin{array}{c}0.0321^{*} \\
(0.0188)\end{array}$ \\
\hline Activity restrictions & & & & $\begin{array}{l}0.0821^{* * *} \\
(0.0266)\end{array}$ \\
\hline Capital regulations & & & & $\begin{array}{c}0.0270 \\
(0.0229)\end{array}$ \\
\hline Observations & 1,556 & 1,551 & 1,543 & 1,501 \\
\hline$R$-squared & 0.253 & 0.287 & 0.289 & 0.255 \\
\hline Number of parents & 67 & 67 & 66 & 66 \\
\hline Number of affiliates & 410 & 409 & 406 & 397 \\
\hline Number of foreign markets & 58 & 58 & 55 & 52 \\
\hline
\end{tabular}

consistent though with our approach to test a theoretical model with data during tranquil pre-crisis times, when liquidity was apparently not a relevant determinant of local lending by affiliates.

This finding corroborates studies that also document how funding structure became especially important to global lending during and after the crisis, but not before (De Haas and Van Lelyveld, 2010, 2014). For our sample of foreign affiliates of German parents, the coefficient in Column (2) estimated for the share of wholesale funding is significantly negative. A larger reliance of affiliates on financial markets, rather than internal capital markets or local depositors reduced their lending capacity.

Larger affiliates lend more as shown by the significantly positive coefficient of log total assets. Therefore, the effects of different affiliate-level traits on foreign lending are not merely reflecting size differentials of affiliate operations, for example of large versus small economies. Beyond sheer size effects, local lending by the affiliate depends also on the capitalization and funding structure of foreign subsidiaries and branches.

The choice of multinational banking through branches and subsidiaries reflects different business activities (e.g., retail activities through subsidiary networks; see Fiorentino, Koch, 
and Rudek, 2010), parent performance traits (Buch, Koch, and Koetter, 2014), and foreign market restrictions in terms of regulation and supervision, which we investigate more closely below. In our sample, we find a significantly positive effect of the subsidiary indicator on loan demand by non-financials.

To control more explicitly for time-variant differences across foreign markets $k$, we specify in Column (3) macroeconomic controls that correlate with credit markets-the relative credit market size in foreign countries, competition from other than German parents, and GDP per capita-together with country-fixed effects. Although the coefficients for these covariates are statistically insignificant, the effect of larger price margins on the local lending by the affiliate remains negative, as do the effects of price margins of other affiliates and local lending of other affiliates.

Column (4) underpins the importance of country factors to explain the variation in local lending by the affiliate. We replace country-fixed effects with three explicit financial system traits that should directly influence financial markets through regulation and the acquisition cost of information. Empirical evide.nce supports the notion that loan demand declines with the distance between banks and customers if information asymmetries become more costly to resolve (e.g., Degryse and Ongena, 2005). Our results confirm that an increase in geographical distance correlates significantly negative with local lending by the affiliate. Regulatory differences across countries also can explain both entry into and the level of lending activities of parents. Ongena, Popov, and Udell (2012) show that relatively tax regulation of parents' financial systems relative to foreign markets where their affiliates reside increases the likelihood and the volume of foreign lending. Tighter activity restrictions increase local lending by the affiliates of German parents.

Dropping country-fixed effects also implies that all other foreign market traits' now exhibit statistically significant effects in line with theoretical predictions. The main variable of interest, the price margin, is now statistically significant at the $1 \%$ level, remains negative, and exhibits a magnitude that is around 35\% larger compared with the parsimonious specification in Column (1). The share of explained variation is substantially lower compared with the fixed effects specification in Column (3), which is therefore our baseline specification from here on.

\section{1.b. Parent funding}

Panel B in Table III shows the parameter estimates for Equation (10). The main variable of interest is the cost margin: the wedge between the funding cost of affiliates in foreign markets $j$ and the cost of funding provided by parents through internal capital markets. The theoretical model predicts a positive relationship because using relatively cheaper parent funding increases affiliate, and thus parent profits.

All specifications in Columns (1)-(4) of panel B exhibit positive coefficient estimates. But when we account for the funding cost margins of other affiliates, the parent funding of other affiliates, parent $\times$ year, and country-fixed effects, the coefficients cannot be estimated sufficiently precise.

In fact, the effect of funding cost margins on internal capital market funding is absorbed by the variable capturing how much funding remains available within the parent. Irrespective of adding controls across columns, an increase of parent funding by other affiliates reduces internal capital market funding of the affiliate itself significantly. This result confirms the evidence for US parents that headquarters allocate and manage internal liquidity actively (Cetorelli and Goldberg, 2012a, 2012b, 2012c) and presumably compete 
internally for funding (Cremers, Huang, and Sautner, 2011). As shown in Columns (3) and (4), we estimate a positive relationship between the funding cost margins of other foreign affiliates and parent funding. Even though this relationship is only weakly significant, a possible explanation for this finding could be that we are not able to measure parent funding cost at the affiliate level, such that at least in our empirical model a drop in parent funding costs equally benefits all affiliates.

With respect to affiliate-level variables, Column (2) shows that an increase in the share of wholesale funding by foreign affiliates correlates negatively with parent funding. Foreign affiliates seem to substitute intra-group with external capital market funding. Bearing in mind that this is a pre-crisis period sample, this result is in line with De Haas and Van Lelyveld (2010, 2014). Parents were not as important to fund subsidiaries through internal capital markets in regular times compared with their role as liquidity provider when the financial crisis hit. They find that specific shocks to one foreign market can be smoothed by financially sound parents. But shocks in parents' domestic markets paired with larger dependence on wholesale funding amplify the contraction of local lending by the affiliate.

In line with expectations, we also find that larger affiliates receive more internal capital market funding. Thus, neither the effect of average funding routed to other affiliates nor the reliance on wholesale funding are merely reflecting size differentials of affiliates. As with local lending by the affiliate, subsidiaries receive more funding from parents through internal capital markets compared with foreign branches.

Column (3) provides little indication that foreign market traits explain a large share of parent funding of foreign affiliates after we account for cross-affiliate differences in parent funding that are captured by parent $\times$ year and country-fixed effects (Cetorelli and Goldberg, 2012c). Only after replacing the latter with time-invariant control variables in Column (4), we obtain some significant estimates for country-level covariates. Given the substantially larger share of explained variance, we prefer to use henceforth the specification in Column (3).

\subsection{Affiliate and Parent Types}

Table I shows that there is a clear distinction between parents that are globally active in many countries versus those that have only few foreign operations. For global parents the benefits of using internal capital markets could be much larger. Also the type of activity conducted by foreign affiliates is likely to differ, depending on whether they operate as a branch or a subsidiary and the extent to which they are able to fund themselves locally.

Therefore, in Table IV we re-estimate the preferred baseline specifications in Columns (3) of Table III, to test if price and funding cost margin effects differ between branches and when foreign affiliates are entirely funded by local deposits without any parent funding. ${ }^{14}$

In Column (1), we specify an indicator variable equal to 1 for branches and 0 for subsidiaries, which we interact with price and funding cost margins. The results in panel A show that our lending results hold mainly for subsidiaries. Price margins exhibit a significantly negative direct effect, but the interaction with the branch dummy is positive. Together, these estimates imply a small positive marginal effect for branches. The results in panel B

14 Note that the results in all subsequent tables also include the price margins and local lending of other affiliates in panel $A$ and the funding cost margins and parent funding of other affiliates in panel B. For brevity these coefficients are not shown. The effects are qualitatively similar to those in Table III. 
Table IV. Affiliate business models and scale of parents

This table reports estimates of Equation (9) in panel A and estimates of Equation (10) in panel B for the years 2003-07 for several subsamples, by interacting margins with indicator variables. The dummy " $X$ " is an indicator variable that equals 1 for each of the respective groups that are indicated in the column headers and 0 otherwise. Branch indicates whether an affiliate is a branch as opposed to a subsidiary. Only local funding indicates that an affiliate is entirely funded with local deposits. Large parents are defined as having total assets larger than the 95th percentile. Global parents have more than the median number of affiliates. The latter two variables are recalculated each year, see also Table I. All estimations include affiliate controls, macro-controls, parent $\times$ year fixed effects and country-fixed effects. All explanatory variables are lagged by one period. Standard errors are clustered at the parent-year level and are reported in parentheses and $* * * * *$, and ${ }^{*}$ correspond to the $1 \%, 5 \%$, and $10 \%$ level of significance, respectively.

\begin{tabular}{|c|c|c|c|c|}
\hline & $\begin{array}{c}(1) \\
\text { Branch }\end{array}$ & $\begin{array}{l}\qquad(2) \\
\text { Only local } \\
\text { funding }\end{array}$ & $\begin{array}{l}\quad(3) \\
\text { Large } \\
\text { parents }\end{array}$ & $\begin{array}{c}\text { (4) } \\
\text { Global } \\
\text { parents }\end{array}$ \\
\hline \multicolumn{5}{|c|}{ Panel A: Local lending by affiliate } \\
\hline Price margin & $\begin{array}{c}-0.0619 * * * \\
(0.0159)\end{array}$ & $\begin{array}{c}-0.0521 * * * \\
(0.0150)\end{array}$ & $\begin{array}{c}-0.0298 * * \\
(0.0129)\end{array}$ & $\begin{array}{r}-0.0135 \\
(0.0211)\end{array}$ \\
\hline Dummy $X$ & $\begin{array}{c}-1.7673 * * \\
(0.3836)\end{array}$ & $\begin{array}{r}-0.2898 \\
(0.2345)\end{array}$ & & \\
\hline Price margin $\times X$ & $\begin{array}{l}0.0673 * * * \\
(0.0154)\end{array}$ & $\begin{array}{l}0.0673 * * * \\
(0.0181)\end{array}$ & $\begin{array}{c}-0.0763 * * \\
(0.0308)\end{array}$ & $\begin{array}{r}-0.0259 \\
(0.0184)\end{array}$ \\
\hline Observations & 1,602 & 1,600 & 1,602 & 1,602 \\
\hline$R$-squared & 0.396 & 0.384 & 0.382 & 0.381 \\
\hline \multicolumn{5}{|l|}{ Panel B: Parent funding } \\
\hline Funding cost margin & $\begin{array}{c}0.0277 \\
(0.0264)\end{array}$ & $\begin{array}{c}0.0292 \\
(0.0236)\end{array}$ & $\begin{array}{c}0.0395 \\
(0.0245)\end{array}$ & $\begin{array}{c}0.0228 \\
(0.0319)\end{array}$ \\
\hline Dummy $X$ & $\begin{array}{c}-0.2017 * \\
(0.1082)\end{array}$ & $\begin{array}{c}0.0614 \\
(0.0779)\end{array}$ & & \\
\hline Funding cost margin $\times X$ & $\begin{array}{c}0.0253 \\
(0.0285)\end{array}$ & $\begin{array}{c}0.0434 \\
(0.0274)\end{array}$ & $\begin{array}{c}0.0716 \\
(0.0809)\end{array}$ & $\begin{array}{c}0.0178 \\
(0.0226)\end{array}$ \\
\hline Observations & 1,543 & 1,541 & 1,543 & 1,543 \\
\hline$R$-squared & 0.289 & 0.288 & 0.288 & 0.288 \\
\hline
\end{tabular}

show that larger funding cost margins have a positive effect on parent funding. As before it is not statistically discernible from zero. The effect of the cost margin does not differ significantly between branches and subsidiaries.

In Column (2), we specify an indicator variable that equals 1 if an affiliate is completely funded by local deposits, thereby not making use of internal capital markets of the parent in terms of parent funding. For both the local lending and the parent funding sample, around one-third of all affiliates are such local funders. However, around 44\% of all branches are local funders whereas only $23 \%$ of all subsidiaries rely solely on local deposits. The results in panel A suggest that the lending results hold mainly when affiliates are active on internal capital markets and also obtain parent funding. The price margin exhibits a significantly negative direct effect, but the interaction with the indicator of complete local funding is positive, which implies overall a small positive marginal effect. Entirely locally 
funded affiliates may command prohibitively small shares of local loan markets, such that their choices on local lending do not affect rates a lot. Indeed, the mean size of only locally funded affiliates is around 0.8 billion Euros compared with a mean affiliate size of around 6.7 billion Euros. Accordingly, they might be acting as price takers and expand supply of their local lending when price margins increase. In contrast, affiliates that obtain parent funding seem to use the access to a large pool of funding to make local loan choices that permit the extraction of rents, as in Park and Pennacchi (2009). The results in panel B further show that the effect of the cost margin is not significantly different for those affiliates that only receive local funding.

Next we investigate the differential effect of price and funding cost margin effects depending on the scale of parent operations: large versus small and global versus international parents. The results in Column (3) and (4) investigate the effect of price and funding cost margins for large and global parents. The large parent indicator equals 1 if total assets are larger than the 95th percentile of the annual distribution of parents' total assets. As in Table I, we define an indicator variable equal to 1 for those parents with more affiliates than the median number of affiliates in each year to distinguish global from international parents. Because both indicator variables are constant within each parent-year, they are subsumed by the parent-year fixed effect. The results in Columns (3) and (4) indicate that the negative effect of the price margin is amplified for large parents. Qualitatively, this amplification effect seems to also hold for global parent, but it is not statistically significant. With regards to the effect of funding cost margins on parent funding, we do not find significant differences for large and global parents in panel B.

\subsection{Country Groups}

Most international affiliates of German parents operate in industrialized economies (Table AI). Despite the specification of country controls and fixed effects, some important country(-group) effects may still drive our results. Examples are the common currency in the EMU or favorable regulatory and tax regulation in offshore and financial centers. Table $\mathrm{V}$ therefore provides results from interaction models to test the robustness of our main results for price margins (Panel A) and funding cost margins (Panel B) across five different country groups.

The first column distinguishes less developed countries (LDCs), which are particularly sensitive to the transmission of financial shocks through international financial institutions (Cetorelli and Goldberg, 2012a). LDCs are identified according to the World Bank classification. We specify an indicator variable equal to 1 for LDC and interact it with the price margin. The direct effect of the price margin in panel A remains significantly negative. The effects of funding cost margins on the internal capital market funding remain not discernible from zero. Likewise, interaction terms are not significant in either case.

The next two columns consider whether groups of more developed countries, specifically the EMU and the OECD, exhibit significantly different responses to margins in local lending by the affiliate and parent funding. After specification of the EMU indicator and the associated interaction terms the funding cost margin becomes positive and significant as expected. The effect of the price margin is still negative, even though no longer statistically significant. Once we consider the somewhat more heterogeneous sample of OECD countries, we also find statistically significant results for the price margin effect on lending. 
Table V. Country groups

This table reports estimates of Equation (9) in panel A and estimates of Equation (10) in panel B for the years 2003-07 for several country subsamples, by interacting margins with indicator variables. The dummy " $X$ " is an indicator variable that equals 1 for each of the respective country groups that are indicated in the column headers and 0 otherwise. LDC indicates less developed countries as defined by the World Bank. EMU countries are members of the European Monetary Union. OECD indicates member countries of the Organization of Economic Cooperation and Development. Offshore and Financial center countries contained in the estimation sample are defined according to the taxonomy of Bundesbank. The former are the Phillippines, Singapore, and Switzerland; the latter are Luxembourg, Switzerland, and the UK. All estimations include affiliate controls, macro-controls, parent $\times$ year fixed effects, and country-fixed effects. All explanatory variables are lagged by one period. Standard errors are clustered at the parent-year level and are reported in parentheses and ${ }^{* *},{ }^{*}$, and ${ }^{*}$ correspond to the $1 \%, 5 \%$, and $10 \%$ level of significance, respectively.

\begin{tabular}{lccccc}
\hline & $(1)$ & $(2)$ & $(3)$ & $(4)$ & $\begin{array}{c}(5) \\
\text { LDC }\end{array}$ \\
& EMU & OECD & Offshore & $\begin{array}{c}\text { Financial } \\
\text { Center }\end{array}$ \\
\hline Panel A: Local lending by affiliate & & & & \\
Price margin & $-0.0320 * *$ & -0.0154 & $-0.0255^{*}$ & -0.0342 & $-0.0298^{* *}$ \\
& $(0.0145)$ & $(0.0139)$ & $(0.0150)$ & $(0.0218)$ & $(0.0135)$ \\
Dummy $X$ & $-3.2127^{* *}$ & -0.3101 & 0.0409 & $-2.2868 * *$ & -1.4990 \\
& $(1.5887)$ & $(1.4093)$ & $(1.0164)$ & $(0.9821)$ & $(6.8574)$ \\
Price margin $\times X$ & 0.0351 & -0.0335 & -0.0095 & 0.0085 & -0.0694 \\
& $(0.0317)$ & $(0.0238)$ & $(0.0274)$ & $(0.0268)$ & $(0.0859)$ \\
Observations & 1,602 & 1,602 & 1,602 & 1,602 & 1,602 \\
$R$-squared & 0.392 & 0.393 & 0.392 & 0.392 & 0.392 \\
Panel B: Parent funding & & & & & \\
Funding cost margin & 0.0390 & $0.0722^{* *}$ & $0.0663 * *$ & 0.0393 & 0.0386 \\
& $(0.0284)$ & $(0.0346)$ & $(0.0280)$ & $(0.0240)$ & $(0.0242)$ \\
Dummy $X$ & -3.3301 & -1.2051 & 0.2774 & 0.1951 & 3.1588 \\
& $(4.7082)$ & $(1.0400)$ & $(0.7040)$ & $(0.6515)$ & $(4.8056)$ \\
Funding cost margin $\times X$ & -0.0007 & -0.0513 & -0.0331 & 0.0816 & -0.0433 \\
& $(0.0308)$ & $(0.0523)$ & $(0.0371)$ & $(0.0780)$ & $(0.0737)$ \\
Observations & 1,543 & 1,543 & 1,543 & 1,543 & 1,543 \\
$R$-squared & 0.289 & 0.289 & 0.289 & 0.289 & 0.289 \\
\hline
\end{tabular}

The last two columns test the robustness of our main results with regards to the role of offshore destinations and financial centers, as classified by the Bundesbank. ${ }^{15}$ Panel A confirms the negative effect of price margins after specifying an offshore and a financial center indicator variable and the associated interaction terms, which can only be sufficiently precisely estimated for financial centers though. Note that because we consider only lending to non-financials within the foreign markets where the affiliate is located this effect is neither a lending-hub effect, as in Frey and Kerl (2015), in which interbank loans would be distributed only through these markets, nor is it an indication of non-credit banking activities,

15 Included offshore destinations according to the Bundesbank taxonomy are the Philippines, Singapore, and Hong Kong. Financial centers are Luxembourg, Switzerland, and the UK. 
such as security investment or other trading. Panel B illustrates that the effect of funding cost margins is not significantly positive after we specify offshore and financial center indicator variables and their associated interaction terms.

Overall, our main results do not appear to be driven by certain country groups: The specification of different country group indicators confirms the evidence of negative price margin effects on local lending by the affiliate and unveils positive effects of funding cost margins on parent funding in line with theory, when we account for the differences between OECD and non-OECD countries and EMU and non-EMU countries.

\subsection{Lending and Funding Dependence}

Whereas we already account for possible interdependence within parents across affiliates by specifying the margins and volumes of other affiliates, our results may also be driven by cross-equation dependence between local lending by the affiliate and parent funding. ${ }^{16}$ Therefore, we combine Equations (9) and (10) such that local lending depends next to the price margin also on the funding cost margin, parent funding volumes, and associated weighted variables of other affiliates. Likewise, parent funding is explained next to the funding cost margin by the price margin, local lending by the affiliate, and associated weighted variables of other affiliates. All variables are lagged by one period as before. Table VI shows the results.

Replicating the structure of our main estimates from Table III, we find that the results for the local lending by the affiliate equation confirm the theoretically consistent negative effect of price margins. The effect is significant at the $5 \%$ level in our preferred specification when using parent $\times$ year and country-fixed effects and only slightly smaller in terms of magnitude when compared with the baseline effect detected earlier. Across specifications, and like before, larger price margins of other affiliates and local lending of other affiliates within a parent reduce the average affiliates' own lending. With respect to the additional covariates on funding that gauge inter-equation dependence, we find that only larger funding volumes correlate significantly positive in all four specifications with local lending by the affiliate. This result is consistent with De Haas and Van Lelyveld (2014), who estimate a reduced form foreign lending equation conditional on intra-group funding and also report that more internal funding stimulates foreign market lending.

Results to explain parent funding confirm the positive, but insignificant effect of funding cost margins. The three most important factors that are consistently significant across specifications are as follows. First, more local lending of other affiliates reduces the received amounts of parent funding. This suggests indeed that headquarters route scarce internal financial resources to those affiliates that lend the most as suggested by, for example Cetorelli and Goldberg (2012a, 2012b). Second, and related, larger volumes of parent funding by other affiliates, received by competing affiliates in the past period, correlate negatively with net funding received by the average affiliate itself. This might indicate competition among affiliates on internal capital markets as suggested by Cremers, Huang, and Sautner (2011). Third, greater past affiliate lending also triggers more parent funding today.

Overall, the specification confirms the independent effect of price margins on affiliate lending and the absence of statistically significant funding cost margin effects on parent

16 We show in Appendix B how the FOCs in Equations (6) and (8) can imply that local lending by the affiliate and parent funding are chosen simultaneously. 
Table VI. Main estimates including inter-equation dependence

This table reports estimates of Equation (9) in panel A and estimates of Equation (10) in panel B for the years 2003-07, taking into account the theoretical dependence derived in Equations (A.2) and (A.3). Margins and volumes of other affiliates are country-weighted averages of all other affiliates per parent, using the inverse of geographical distance as weight. All explanatory variables are lagged by one period. Standard errors are clustered at the parent-year level and are reported in parentheses and $*^{* *},{ }^{*}$, and ${ }^{*}$ correspond to the $1 \%, 5 \%$, and $10 \%$ level of significance, respectively.

\begin{tabular}{|c|c|c|c|c|}
\hline Panel A: Local lending by affiliate & (1) & (2) & $(3)$ & (4) \\
\hline Price margin & $\begin{array}{c}-0.0274 * * \\
(0.0117)\end{array}$ & $\begin{array}{c}-0.0289 * * * \\
(0.0104)\end{array}$ & $\begin{array}{c}-0.0259 * * \\
(0.0113)\end{array}$ & $\begin{array}{c}-0.0354 * * * \\
(0.0119)\end{array}$ \\
\hline Price margins of other affiliates & $\begin{array}{c}-0.0833 * * \\
(0.0343)\end{array}$ & $\begin{array}{c}-0.1082 * * * \\
(0.0350)\end{array}$ & $\begin{array}{c}-0.1076 * * * \\
(0.0347)\end{array}$ & $\begin{array}{c}-0.1064 * * * \\
(0.0340)\end{array}$ \\
\hline Funding cost margin & $\begin{array}{c}-0.0575 * \\
(0.0257)\end{array}$ & $\begin{array}{r}-0.0072 \\
(0.0295)\end{array}$ & $\begin{array}{r}-0.0172 \\
(0.0452)\end{array}$ & $\begin{array}{c}0.0010 \\
(0.0219)\end{array}$ \\
\hline Funding cost margins of other affiliates & $\begin{array}{c}-0.0601 * * \\
(0.0277)\end{array}$ & $\begin{array}{r}-0.0273 \\
(0.0343)\end{array}$ & $\begin{array}{r}-0.0314 \\
(0.0379)\end{array}$ & $\begin{array}{r}-0.0120 \\
(0.0363)\end{array}$ \\
\hline Local lending of other affiliates & $\begin{array}{l}-0.2021 * * * \\
(0.0235)\end{array}$ & $\begin{array}{c}-0.2191 * * * \\
(0.0283)\end{array}$ & $\begin{array}{c}-0.2194 * * * \\
(0.0287)\end{array}$ & $\begin{array}{c}-0.2123 * * \\
(0.0179)\end{array}$ \\
\hline Parent funding of other affiliates & $\begin{array}{r}-0.0085 \\
(0.0893)\end{array}$ & $\begin{array}{c}0.0104 \\
(0.0984)\end{array}$ & $\begin{array}{c}0.0136 \\
(0.0987)\end{array}$ & $\begin{array}{c}0.0658 \\
(0.0968)\end{array}$ \\
\hline Parent funding (lagged) & $\begin{array}{l}0.6174 * * * \\
(0.1150)\end{array}$ & $\begin{array}{l}0.5113 * * * \\
(0.0952)\end{array}$ & $\begin{array}{l}0.5123 * * * \\
(0.0951)\end{array}$ & $\begin{array}{l}0.5091 * * * \\
(0.1020)\end{array}$ \\
\hline Observations & 1,556 & 1,551 & 1,543 & 1,501 \\
\hline$R$-squared & 0.272 & 0.448 & 0.447 & 0.379 \\
\hline Affiliate controls & No & Yes & Yes & Yes \\
\hline Time-varying macro-controls & No & No & Yes & Yes \\
\hline Non time-varying macro-controls & No & No & No & Yes \\
\hline Parent $\times$ year FE & Yes & Yes & Yes & Yes \\
\hline Country-fixed effects & Yes & Yes & Yes & No \\
\hline Number of parents & 67 & 67 & 66 & 66 \\
\hline Number of affiliates & 410 & 409 & 406 & 397 \\
\hline Number of foreign markets & 58 & 58 & 55 & 52 \\
\hline Panel B: Parent funding & $(1)$ & $(2)$ & (3) & (4) \\
\hline Price margin & $\begin{array}{c}0.0038 \\
(0.0082)\end{array}$ & $\begin{array}{c}0.0038 \\
(0.0085)\end{array}$ & $\begin{array}{r}-0.0030 \\
(0.0094)\end{array}$ & $\begin{array}{c}0.0044 \\
(0.0069)\end{array}$ \\
\hline Price margins of other affiliates & $\begin{array}{r}-0.0119 \\
(0.0172)\end{array}$ & $\begin{array}{r}-0.0120 \\
(0.0177)\end{array}$ & $\begin{array}{r}-0.0158 \\
(0.0187)\end{array}$ & $\begin{array}{r}-0.0304 \% \\
(0.0165)\end{array}$ \\
\hline Funding cost margin & $\begin{array}{c}0.0116 \\
(0.0249)\end{array}$ & $\begin{array}{c}0.0025 \\
(0.0245)\end{array}$ & $\begin{array}{c}0.0318 \\
(0.0252)\end{array}$ & $\begin{array}{c}0.0120 \\
(0.0135)\end{array}$ \\
\hline Funding cost margins of other affiliates & $\begin{array}{c}0.0318 \\
(0.0220)\end{array}$ & $\begin{array}{c}0.0250 \\
(0.0221)\end{array}$ & $\begin{array}{c}0.0369 \\
(0.0227)\end{array}$ & $\begin{array}{c}0.0268 \\
(0.0169)\end{array}$ \\
\hline Local lending of other affiliates & $\begin{array}{c}-0.0604 * * \\
(0.0238)\end{array}$ & $\begin{array}{c}-0.0599 * * \\
(0.0256)\end{array}$ & $\begin{array}{c}-0.0586 * * \\
(0.0260)\end{array}$ & $\begin{array}{c}-0.0419 * * \\
(0.0172)\end{array}$ \\
\hline Parent funding of other affiliates & $\begin{array}{c}-0.7401 * * * \\
(0.0668)\end{array}$ & $\begin{array}{c}-0.7427 * * * \\
(0.0647)\end{array}$ & $\begin{array}{c}-0.7433 * * * \\
(0.0647)\end{array}$ & $\begin{array}{c}-0.7604 * * \\
(0.0687)\end{array}$ \\
\hline Local lending of affiliate (lagged) & $\begin{array}{l}0.1414 * * * \\
(0.0227)\end{array}$ & $\begin{array}{l}0.1401 * * * \\
(0.0241)\end{array}$ & $\begin{array}{l}0.1403 * * * \\
(0.0241)\end{array}$ & $\begin{array}{l}0.1314 * * * \\
(0.0221)\end{array}$ \\
\hline
\end{tabular}


Table VI. Continued

\begin{tabular}{lcccc}
\hline Panel B: Parent funding & $(1)$ & $(2)$ & $(3)$ & $(4)$ \\
\hline Observations & 1,556 & 1,551 & 1,543 & 1,501 \\
$R$-squared & 0.345 & 0.358 & 0.360 & 0.328 \\
Affiliate controls & No & Yes & Yes & Yes \\
Time-varying macro-controls & No & No & Yes & Yes \\
Non time-varying macro-controls & No & No & No & Yes \\
Parent $\times$ year FE & Yes & Yes & Yes & Yes \\
Country-fixed effects & Yes & Yes & Yes & No \\
Number of parents & 67 & 67 & 66 & 66 \\
Number of affiliates & 410 & 409 & 406 & 397 \\
Number of foreign markets & 58 & 58 & 55 & 52 \\
\hline
\end{tabular}

funding for the entire sample. Significant lagged dependent variables corroborate the active internal capital market management suggested in Cetorelli and Goldberg (2012c).

\subsection{Robustness}

All robustness results are compiled in an Online Appendix to conserve space.

\section{5.a. Weighting schemes of other affiliate margins and volumes}

Foreign affiliates are likely to compete on internal capital markets for parent funds to originate affiliate lending in foreign markets. Therefore, we specify price and funding cost margins of other affiliates as well as local lending and parent funding of other affiliates using the inverse geographic distance between the markets $k$ where affiliates $j$ operate. However, headquarters in Germany may manage affiliates more like a portfolio of imperfectly correlated risks when allocating funding and imposing credit granting procedures. Therefore, we show in Table OA2 in the Online Appendix the baseline results when using the correlation of GDP across each country $k$ where affiliates $j$ of parent $i$ operate in the five preceding years as a weighting scheme.

The results are very similar to the baseline results reported before. Larger price margins reduce local lending by the affiliate whereas local lending by other affiliates as well as price margins of other affiliates of the parent continue to exert significantly negative effects on local lending by the affiliate. Likewise, funding cost margins remain insignificant in explaining parent funding and more parent funding of other affiliates weighted with GDP-correlation continues to suggest a crowding out of available internal capital market funds.

\section{5.b. Alternative fixed effect specification}

The preferred baseline specification relies on parent $\times$ year and country-fixed effects to control for unobservables and affiliate-level and country covariates to explain local lending by the affiliate and parent funding. As an alternative, Table OA3 in the Online Appendix reproduces the baseline results using only direct fixed effects for countries, parents, and years and explicit parent-level controls. These variables are defined in Table AII and capture financial profiles of parents. We include the size, liquidity, credit risk, cost-to-income ratio, capitalization, return on equity, $z$-score, and wholesale funding reliance per parent. The main result of a significantly negative effect of price margins on affiliate lending 
remains intact. Likewise, the absence of a statistically significantly positive effect of funding cost margins on parent funding is also confirmed.

\section{5.c. Selection bias}

Parents do not enter foreign markets randomly. Entry choices likely depend on both bank and country traits at home and abroad (Claessens and van Horen, 2014a, 2014b). To control for possible selection bias, we show in Table OA4 in the Online Appendix the results from the procedure outlined in Wooldridge (2010) to account for selection bias. First, we estimate a pooled Probit model at the parent-foreign market level, such that we aggregate all affiliates $j$ of a parent $i$ within a certain market $k$ into one unit of analysis. Second, we rectangularize the data set, such that parents could enter any of the fifty-eight foreign markets sampled in the parsimonious specifications in Table III. Third, conditional on parent and country traits, we estimate a selection equation using a probit model for this large sample of around 460,000 parent-country-year observations. The dependent variable equals 1 if parent $i$ is observed to operate an affiliate in market $k$ at time $t$. The variables Distance, Activity Restrictions, and Capital Regulations are the exclusionary restrictions. Fourth, we generate an inverse Mill's ratio and specify it in the local lending by the affiliate and parent funding equations to test for the presence of selection bias.

Results for the lending equation are depicted in the top panel of Table OA4 in the Online Appendix. The inverse Mill's ratio is significant, thus accepting the hypothesis of a selection bias. We follow Wooldridge (2010) and control for that bias by interacting the (stacked) inverse Mill's ratio from the Probit selection equations estimated for each country interacted with country dummies. The effect of price margins remains significantly negative in the last column (column "Heckman2"), thereby confirming the main result reported here.

For the parent funding equation results in panel B, we also find a significant inverse Mill's ratio. But as for the baseline estimations, funding cost margins remain statistically not discernible from zero once we specify interaction terms to correct for the selection bias. As reported throughout, explaining parent funding with funding cost margins suffers from a lack of precision that precludes significant point estimates in the entire sample of parents and countries during pre-crisis times.

Overall, selection bias appears not to affect the qualitative implications of the empirical results reported so far. We find robust confirmation of the theoretical predictions that larger price margins reduce local lending by the affiliate, whereas the evidence that larger funding cost margins spur parent funding is statistically weaker.

\section{5.d. Margin construction and measurement}

Another concern relates to the construction of the two margins. Recall that we augment median interest rates on loans and deposits obtained from bank-level Bankscope data with macroeconomic interest rate series from the WDI database of the World Bank. To ensure that the different sources used for these key variables do not drive the results, we also specify margins that are exclusively based on each source in Table OA5 in the Online Appendix.

The sample based on Bankscope data alone is almost identical to the baseline sample. The results for the price and funding cost margins on lending and funding choices hardly differ from the full sample. Specifications relying on WDI-based margins alone entail a more substantial reduction of observations by approximately $50 \%$. Estimates are accordingly insignificant for both price and funding cost margins. 
We also assess in Table OA5 in the Online Appendix if the measurement of local lending by the affiliate and parent funding in billions of Euro-which exhibits the usual skew in firm size distributions (see Buch, Koch, and Koetter, 2011b)—drives the documented effects. First, we subdue the effect of extreme values by specifying the share of affiliate lending and parent funding relative to total affiliate assets rather than including log affiliate assets directly as control. Second, we replace local lending by the affiliate and parent funding by total assets and total liabilities, respectively, to determine whether the predictions of our theoretical model are still longer supported when we allow for other affiliate activities, such as interbank lending, security trading, or wholesale funding. Third, we mitigate the effect of outliers by simply considering the log of local lending by the affiliate and parent funding. Qualitatively most tests confirm the baseline specification results. Statistical significance is somewhat lower. But the tests-especially the last one-largely confirm the negative effect of price margins and the positive effect of funding cost margins.

\section{Conclusion}

We develop a simple theory of multinational parent banks and their foreign affiliates in the spirit of an imperfect competition Monti-Klein model to explain local lending in foreign markets as well as parent funding of these affiliates. Thereby, we shed light on the interaction between the internal capital market of international parents and local lending activities in foreign markets through networks of foreign affiliates. The suggested model introduces price margins to explain the local lending by affiliates and funding cost margins to explain parent funding of affiliates. Price margins are the difference between loan and deposit rates in foreign markets faced by affiliates. Funding cost margins gauge the difference between the funding cost in foreign markets relative to the cost of parent funding, which is transmitted to affiliates through internal capital markets.

Based on rich parent- and affiliate-level data of all German parents that are internationally active with foreign affiliates, we test our theoretical model empirically during a tranquil period prior to the financial crisis. Using parent $\times$ year and country-fixed effects jointly with rarely available affiliate-level data, we find clear evidence that price margins explain local lending by the affiliates of German parents between 2003 and 2007 well. This effect is economically significant: an increase of price margins by one standard deviation reduces affiliate lending by around $20 \%$.

Besides the negative effect of price margins on affiliate lending, we find evidence of competition among affiliates within parents. Larger price margins of other affiliates as well as more local lending of other affiliates within a parent reduce local lending by the average affiliate itself. These disposition effects confirm studies that report how parent headquarters actively manage internal capital markets on a global scale.

The positive effect of funding cost margins on parent funding is statistically much weaker, although qualitatively in line with the theoretical prediction. But for more homogenous subsamples, such as OECD and EMU countries, the expected positive effect of funding cost advantages of parents relative to foreign markets on parent funding provided to foreign affiliates is statistically significant. The evidence therefore indicates a potentially important role for the internal capital markets of parents to fund foreign affiliates, and thus a possible channel for the transmission of monetary policy and shocks.

We also show that foreign affiliates that are solely funded on local deposit markets do not contract local lending in response to increasing price margins, but conversely appear to 
slightly expand their lending. This result might indicate less ability to affect loan rates in foreign markets if that affiliate has not access to a large pool of parent funding. Foreign affiliates of the largest parents, in turn, exhibit a significantly amplified negative relationship of price margins and local lending by the affiliate. This result possibly indicates that these larger internal capital markets provide foreign affiliates with more muscle to affect loan rates in foreign markets due to contracted local lending.

Most results are robust across a range of alternative specifications and tests, such as the effect of choices at other affiliates within a parent's network, alternative measurement of local lending and parent funding, various sources and definitions of price and funding cost margins, an explicit account of interdependence between local lending and parent funding, corrections for self-selection of parents into international activities by means of affiliates, as well as alternative fixed effect specifications and variables constructions schemes.

Overall, the simple theoretical model suggested in this article gauges a fairly general mechanism how interest margins determine parents' choices concerning their foreign affiliates. We test a number of implications empirically using a comprehensive sample of all German parents and affiliates during tranquil, non-crisis times. This evidence clearly indicates an important interaction between actively managed internal capital markets of international parent banks and foreign affiliates.

\section{Supplementary Material}

Supplementary data are available at Review of Finance online.

\section{Appendix A}

\section{Table Al. Countries}

This table presents an overview of the countries in the local lending by affiliates and the parent funding estimation samples (see Column (3) of Table III) and the raw data. Freq. indicates the number of observations, Percent indicates the percentage associated with each country, and Av.\#Aff. indicates the average number of affiliates present in each country during the sample period 2003-07.

\begin{tabular}{|c|c|c|c|c|c|c|c|c|c|}
\hline \multirow[b]{2}{*}{ Country Name } & \multicolumn{3}{|c|}{ Local lending sample } & \multicolumn{3}{|c|}{ Parent funding sample } & \multicolumn{3}{|c|}{ Raw data } \\
\hline & Freq. & Percent & Av.\#Aff. & Freq. & Percent & Av.\#Aff. & Freq. & Percent & Av.\#Aff. \\
\hline Argentina & 5 & 0.31 & 1.00 & 5 & 0.32 & 1.00 & 6 & 0.28 & 1.00 \\
\hline Australia & 12 & 0.75 & 2.50 & 12 & 0.78 & 2.50 & 15 & 0.70 & 2.60 \\
\hline Austria & 101 & 6.30 & 23.34 & 95 & 6.16 & 23.41 & 134 & 6.26 & 23.19 \\
\hline Belgium & 40 & 2.50 & 9.05 & 40 & 2.59 & 9.05 & 55 & 2.57 & 9.22 \\
\hline Bosnia and Herz. & 8 & 0.50 & 3.25 & 8 & 0.52 & 3.25 & 13 & 0.61 & 3.00 \\
\hline Brazil & 15 & 0.94 & 3.67 & 15 & 0.97 & 3.67 & 20 & 0.93 & 3.50 \\
\hline Bulgaria & 4 & 0.25 & 1.75 & 4 & 0.26 & 1.75 & 6 & 0.28 & 1.67 \\
\hline Canada & 26 & 1.62 & 6.12 & 26 & 1.69 & 6.12 & 34 & 1.59 & 6.35 \\
\hline Chile & 6 & 0.37 & 1.50 & 6 & 0.39 & 1.50 & 8 & 0.37 & 1.50 \\
\hline China & 28 & 1.75 & 6.04 & 28 & 1.81 & 6.04 & 35 & 1.63 & 5.91 \\
\hline Croatia & 8 & 0.50 & 2.25 & 8 & 0.52 & 2.25 & 11 & 0.51 & 2.45 \\
\hline Czech Republic & 28 & 1.75 & 6.14 & 28 & 1.81 & 6.14 & 37 & 1.73 & 6.84 \\
\hline Denmark & 7 & 0.44 & 1.86 & 7 & 0.45 & 1.86 & 12 & 0.56 & 2.17 \\
\hline
\end{tabular}


Table Al. Continued

\begin{tabular}{|c|c|c|c|c|c|c|c|c|c|}
\hline \multirow[b]{2}{*}{ Country Name } & \multicolumn{3}{|c|}{ Local lending sample } & \multicolumn{3}{|c|}{ Parent funding sample } & \multicolumn{3}{|c|}{ Raw data } \\
\hline & Freq. & Percent & Av.\#Aff. & Freq. & Percent & Av.\#Aff. & Freq. & Percent & Av.\#Aff. \\
\hline Estonia & 2 & 0.12 & 1.00 & 2 & 0.13 & 1.00 & 3 & 0.14 & 1.00 \\
\hline Finland & 12 & 0.75 & 2.67 & 12 & 0.78 & 2.67 & 16 & 0.75 & 2.75 \\
\hline France & 75 & 4.68 & 17.29 & 67 & 4.34 & 17.28 & 107 & 5.00 & 18.05 \\
\hline Greece & 15 & 0.94 & 3.73 & 10 & 0.65 & 3.80 & 20 & 0.93 & 3.50 \\
\hline Hong Kong & 42 & 2.62 & 8.95 & 42 & 2.72 & 8.95 & 54 & 2.52 & 9.15 \\
\hline Hungary & 38 & 2.37 & 7.92 & 33 & 2.14 & 7.94 & 48 & 2.24 & 8.13 \\
\hline India & 7 & 0.44 & 1.57 & 7 & 0.45 & 1.57 & 10 & 0.47 & 2.00 \\
\hline Indonesia & 9 & 0.56 & 2.00 & 9 & 0.58 & 2.00 & 11 & 0.51 & 1.91 \\
\hline Iran, Islamic Republic & 0 & 0.00 & 0.00 & 0 & 0.00 & 0.00 & 3 & 0.14 & 1.00 \\
\hline Ireland & 64 & 4.00 & 13.45 & 64 & 4.15 & 13.45 & 84 & 3.92 & 14.45 \\
\hline Italy & 56 & 3.50 & 13.32 & 55 & 3.56 & 13.27 & 81 & 3.78 & 13.72 \\
\hline Japan & 29 & 1.81 & 5.97 & 29 & 1.88 & 5.97 & 36 & 1.68 & 6.17 \\
\hline Korea, Republic & 5 & 0.31 & 1.00 & 5 & 0.32 & 1.00 & 6 & 0.28 & 1.00 \\
\hline Latvia & 6 & 0.37 & 1.83 & 6 & 0.39 & 1.83 & 9 & 0.42 & 1.89 \\
\hline Lithuania & 8 & 0.50 & 2.13 & 8 & 0.52 & 2.13 & 12 & 0.56 & 2.33 \\
\hline Luxembourg & 201 & 12.55 & 46.00 & 188 & 12.18 & 45.98 & 286 & 13.35 & 48.46 \\
\hline Malaysia & 21 & 1.31 & 4.43 & 21 & 1.36 & 4.43 & 26 & 1.21 & 4.54 \\
\hline Mauritius & 5 & 0.31 & 1.00 & 5 & 0.32 & 1.00 & 6 & 0.28 & 1.00 \\
\hline Mexico & 4 & 0.25 & 1.50 & 4 & 0.26 & 1.50 & 6 & 0.28 & 1.67 \\
\hline The Netherlands & 49 & 3.06 & 10.41 & 49 & 3.18 & 10.41 & 65 & 3.03 & 10.94 \\
\hline New Zealand & 5 & 0.31 & 1.00 & 5 & 0.32 & 1.00 & 6 & 0.28 & 1.00 \\
\hline Norway & 10 & 0.62 & 2.20 & 4 & 0.26 & 2.00 & 13 & 0.61 & 2.23 \\
\hline Pakistan & 5 & 0.31 & 1.00 & 5 & 0.32 & 1.00 & 6 & 0.28 & 1.00 \\
\hline Panama & 3 & 0.19 & 1.00 & 3 & 0.19 & 1.00 & 4 & 0.19 & 1.00 \\
\hline Philippines & 5 & 0.31 & 1.00 & 5 & 0.32 & 1.00 & 6 & 0.28 & 1.00 \\
\hline Poland & 54 & 3.37 & 11.74 & 53 & 3.43 & 11.81 & 71 & 3.31 & 12.18 \\
\hline Portugal & 10 & 0.62 & 2.00 & 9 & 0.58 & 2.00 & 14 & 0.65 & 2.57 \\
\hline Romania & 6 & 0.37 & 2.00 & 6 & 0.39 & 2.00 & 10 & 0.47 & 2.20 \\
\hline Russia & 21 & 1.31 & 4.43 & 21 & 1.36 & 4.43 & 26 & 1.21 & 4.38 \\
\hline Saudi Arabia & 0 & 0.00 & 0.00 & 0 & 0.00 & 0.00 & 2 & 0.09 & 1.00 \\
\hline Singapore & 72 & 4.49 & 15.07 & 72 & 4.67 & 15.07 & 91 & 4.25 & 15.26 \\
\hline Slovak Republic & 9 & 0.56 & 2.11 & 9 & 0.58 & 2.11 & 12 & 0.56 & 2.17 \\
\hline Slovenia & 4 & 0.25 & 1.00 & 4 & 0.26 & 1.00 & 5 & 0.23 & 1.00 \\
\hline South Africa & 10 & 0.62 & 2.00 & 10 & 0.65 & 2.00 & 12 & 0.56 & 2.00 \\
\hline Spain & 42 & 2.62 & 9.24 & 41 & 2.66 & 9.20 & 55 & 2.57 & 9.25 \\
\hline Sri Lanka & 0 & 0.00 & 0.00 & 0 & 0.00 & 0.00 & 6 & 0.28 & 1.00 \\
\hline Sweden & 20 & 1.25 & 4.70 & 19 & 1.23 & 4.79 & 29 & 1.35 & 5.28 \\
\hline Switzerland & 78 & 4.87 & 16.42 & 76 & 4.93 & 16.43 & 101 & 4.72 & 16.90 \\
\hline Thailand & 5 & 0.31 & 1.00 & 5 & 0.32 & 1.00 & 6 & 0.28 & 1.00 \\
\hline Turkey & 10 & 0.62 & 2.00 & 10 & 0.65 & 2.00 & 12 & 0.56 & 2.00 \\
\hline Ukraine & 4 & 0.25 & 1.00 & 4 & 0.26 & 1.00 & 5 & 0.23 & 1.00 \\
\hline UK & 211 & 13.17 & 44.61 & 202 & 13.09 & 44.59 & 271 & 12.65 & 45.24 \\
\hline USA & 74 & 4.62 & 15.26 & 74 & 4.80 & 15.26 & 93 & 4.34 & 15.60 \\
\hline Uruguay & 3 & 0.19 & 1.00 & 3 & 0.19 & 1.00 & 5 & 0.23 & 1.00 \\
\hline Vietnam & 5 & 0.31 & 0.00 & 5 & 0.32 & 0.00 & 6 & 0.28 & 0.00 \\
\hline Total & 1,602 & 100.00 & 6.50 & 1,543 & 100.00 & 6.50 & 2,142 & 100.00 & 6.40 \\
\hline
\end{tabular}


Table All. Variable definitions

This table defines variables and provides the sources of data. BS, Bankscope; BBK, Deutsche Bundesbank; WDI, the World Development Indicators database; WB, the Worldbank; GDP, Gross Domestic Product.

\begin{tabular}{|c|c|}
\hline Name and acronym & Source and definition \\
\hline \multicolumn{2}{|l|}{ Dependent variables } \\
\hline Local lending by the & BBK. Local lending by foreign affiliates to non-financial \\
\hline affiliate $\left(L_{i j k t}\right)$ & $\begin{array}{l}\text { firms and households that reside in the foreign market } \\
\text { measured in billions of Euros. Winsorized at } 1 \% \text {. }\end{array}$ \\
\hline Parent funding $\left(F_{i j k t}\right)$ & $\begin{array}{l}\text { BBK. Foreign affiliate liabilities minus assets vis-à-vis } \\
\text { parents, that is, net funding, in billions of Euros. Winsorized at } 1 \% \text {. }\end{array}$ \\
\hline \multicolumn{2}{|l|}{ Model } \\
\hline Lending rate $\left(R_{k t-1}^{L}\right)$ & $\begin{array}{l}\text { BS and WDI. The country-year average of } \\
\text { total interest income over gross loans from Bankscope, replaced } \\
\text { with lending rates from WDI if missing. Winsorized at } 1 \% \text {. }\end{array}$ \\
\hline Deposit rate $\left(R_{k t-1}^{D}\right)$ & $\begin{array}{l}\text { BS and WDI. The country-year average of total interest } \\
\text { expenses over total deposits from Bankscope, replaced } \\
\text { with deposit rates from WDI if missing. Winsorized at } 1 \% \text {. }\end{array}$ \\
\hline Parent funding rate $\left(R_{i t-1}^{F}\right)$ & $\begin{array}{l}\text { BBK. Parent interest expenses from unconsolidated } \\
\text { statements as a } \% \text { of total borrowed funds. Winsorized at } 1 \% \text {. }\end{array}$ \\
\hline Price margin $\left(M_{k t-1}^{P}\right)$ & $\begin{array}{l}\text { BS and WDI. Difference between Lending rate } R_{k t-1}^{L} \\
\text { and Deposit rate } R_{k t-1}^{D} \text {. Winsorized at } 1 \% \text {. }\end{array}$ \\
\hline Funding cost margin $\left(M_{i k t-1}^{C}\right)$ & $\begin{array}{l}\text { BS, WDI, and BBK. Difference between Parent } \\
\text { funding rate } R_{i t-1}^{F} \text { and Deposit rate } R_{k t-1}^{D} \text {. Winsorized at } 1 \% \text {. }\end{array}$ \\
\hline Price margins & BS and WDI. Country-weighted average per \\
\hline of other affiliates $\left(M_{i k t-1}^{P, \text { oth. }}\right)$ & parent-year of other affiliates' price margins. \\
\hline Local lending & BBK. Country-weighted average per parent-year \\
\hline of other affiliates $\left(L_{i k t-1}^{\text {Oth. }}\right)$ & of other affiliates' lending. \\
\hline Funding cost margins & BS, WDI, and BBK. Country-weighted \\
\hline of other affiliates $\left(M_{i k t-1}^{C, \text { Oth. }}\right)$ & average per parent-year of other affiliates' funding cost margins. \\
\hline Parent funding & BBK. Country-weighted average per parent-year \\
\hline of other affiliates $\left(F_{i k t-1}^{\text {Oth. }}\right)$ & of other affiliates' parent funding. \\
\hline \multicolumn{2}{|l|}{ Parent variables $\left(X_{i t-1}\right)$} \\
\hline $\ln$ (Total assets) & $\begin{array}{l}\text { BBK. Natural logarithm of unconsolidated parent } \\
\text { total assets in millions of Euro. }\end{array}$ \\
\hline Liquidity & $\begin{array}{l}\text { BBK. Cash and cash with central banks as } \\
\text { a \% of total assets. }\end{array}$ \\
\hline Credit risk & BBK. \% of non-financial non-performing loans. \\
\hline Cost-to-income ratio & BBK. Administrative costs as a ratio of total income \\
\hline Equity ratio & BBK. Total equity as a $\%$ of total assets. \\
\hline Return on equity & BBK. Net income as a $\%$ of total equity. \\
\hline$Z$-score & $\begin{array}{l}\text { BBK. Sum of return on assets and the equity ratio, } \\
\text { divided by the standard deviation of return on assets. }\end{array}$ \\
\hline Wholesale funding & BBK. Securitized debt as a \% of total debt. \\
\hline \multicolumn{2}{|l|}{ Affiliate variables $\left(X_{j-1}\right)$} \\
\hline Aff. Equity ratio & BBK. Total equity as a $\%$ of assets. \\
\hline Aff. Liquidity & $\begin{array}{l}\text { BBK. Cash and cash with central banks as } \\
\text { a \% of total assets. }\end{array}$ \\
\hline
\end{tabular}


Table All. Continued

\begin{tabular}{|c|c|}
\hline Name and acronym & Source and definition \\
\hline Aff. Wholesale funding & BBK. Securitized debt as a \% of total debt. \\
\hline $\ln$ (Aff. total assets) & $\begin{array}{l}\text { BBK. Natural logarithm of affiliate total assets } \\
\text { in millions of Euros. }\end{array}$ \\
\hline \multicolumn{2}{|l|}{ Macro-variables $\left(X_{k t-1}\right)$} \\
\hline Credit to GDP & WDI. Domestic credit as a \% of GDP. \\
\hline Foreign owned banks & Claessens and van Horen (2014a). \% of foreign-owned banks. \\
\hline GDP per capita & WDI. GDP per capita in constant 2005 dollars. \\
\hline Distance & CEPII. Distance between most populated cities in km thousands. \\
\hline \multirow[t]{8}{*}{ Activity restrictions } & $\begin{array}{l}\text { Barth, Caprio, and Levine (2001). Activity restrictions index. Sum } \\
\text { of three }\end{array}$ \\
\hline & subindexes: the extent to which banks may engage in (1) \\
\hline & underwriting, brokering and dealing in securities, and all aspects \\
\hline & of the mutual fund industry; (2) insurance underwriting \\
\hline & and selling, and (3) real estate investment and development. \\
\hline & Unrestricted $=1$; Permitted $=2 ;$ Restricted $=3$; Prohibited $=4$. \\
\hline & Higher values indicate greater restrictiveness. \\
\hline & 2003 version of database. \\
\hline \multirow[t]{6}{*}{ Capital regulations } & $\begin{array}{l}\text { Barth, Caprio, and Levine (2001). Capital regulation index. The } \\
\text { sum of initial }\end{array}$ \\
\hline & capital stringency and overall capital regulatory stringency, \\
\hline & which measures whether certain funds may be used initially \\
\hline & to capitalize a bank and whether they are officially verified. \\
\hline & A higher value indicates greater stringency. \\
\hline & 2003 version of database. \\
\hline
\end{tabular}

\section{Appendix B: Price and Funding Cost Margin Dependence}

In this appendix, we equate the parent's FOCs to show that the optimal amounts of local lending by affiliates can be written as a function of the optimal amount of parent funding and the price and funding cost margins of other affiliates. Likewise, the optimal amount of parent funding can be written as a function of the optimal amount of local lending by the affiliate and the price and funding cost margins of other affiliates. First we equate the parent's FOCs:

$$
\begin{gathered}
R_{i j}^{\prime L}\left(L_{i j}\right) L_{i j}+R_{i j}^{L}-R_{i j}^{D}+\sum_{j \neq m}^{n} R_{i j}^{\prime} L\left(L_{i j}\right) L_{i j}+R_{i j}^{L}-R_{i j}^{D}= \\
-R_{i j}^{\prime F}\left(F_{i j}\right) F_{i j}+R_{i j}^{D}-R_{i j}^{F}-\sum_{j \neq m}^{n} R_{i j}^{\prime F}\left(F_{i j}\right) F_{i j}+R_{i j}^{D}-R_{i j}^{F} .
\end{gathered}
$$

Now we rewrite Equation (A.1) in terms of optimal amount of local lending by the affiliate $L_{i j}^{*}$ :

$$
\begin{aligned}
L_{i j}^{*}= & \frac{R_{i j}^{L}-R_{i j}^{D}}{-R_{i j}^{\prime L}}+\frac{1}{-R_{i j}^{\prime L}} \sum_{j \neq m}^{n} R_{i j}^{\prime L}\left(L_{i j}^{*}\right) L_{i j}^{*}+\frac{1}{-R_{i j}^{\prime L}} \sum_{j \neq m}^{n} R_{i j}^{L}-R_{i j}^{D} \\
& +\frac{R_{i j}^{\prime F}\left(F_{i j}^{*}\right)}{-R_{i j}^{\prime L}} F_{i j}^{*}+\frac{R_{i j}^{D}-R_{i j}^{F}}{-R_{i j}^{\prime L}}-\frac{1}{-R_{i j}^{\prime}} \sum_{j \neq m}^{n} R_{i j}^{\prime F}\left(F_{i j}^{*}\right) F_{i j}^{*}+\frac{1}{-R_{i j}^{\prime \prime}} \sum_{j \neq m}^{n} R_{i j}^{D}-R_{i j}^{F} .
\end{aligned}
$$


In addition to the terms we had in the lending equation before, the second line of Equation (A.2) shows that $L_{i j}^{*}$ is also a function of the optimal amount of parent funding, $F_{i j}^{*}$, and the funding cost margin $R_{i j}^{D}-R_{i j}^{F}$ of foreign affiliate $j$, as well as the sums of the amount of parent funding and funding cost margins of all other affiliates $j \neq m$ of parent $i$. Next, we rewrite Equation (A.1) in terms of the optimal amount of parent funding $F_{i j}^{*}$ :

$$
\begin{aligned}
F_{i j}^{*}= & \frac{R_{i j}^{D}-R_{i j}^{F}}{R_{i j}^{\prime F}}-\frac{1}{R_{i j}^{\prime F}} \sum_{j \neq m}^{n} R_{i j}^{\prime F}\left(F_{i j}^{*}\right) F_{i j}^{*}-\frac{1}{R_{i j}^{\prime F}} \sum_{j \neq m}^{n} R_{i j}^{D}-R_{i j}^{F} \\
& -\frac{R_{i j}^{\prime L}\left(L_{i j}^{*}\right)}{R_{i j}^{\prime F}} L_{i j}^{*}-\frac{R_{i j}^{L}-R_{i j}^{D}}{R_{i j}^{\prime F}}-\frac{1}{R_{i j}^{\prime F}} \sum_{j \neq m}^{n} R_{i j}^{\prime L}\left(L_{i j}^{*}\right) L_{i j}^{*}-\frac{1}{R_{i j}^{\prime F}} \sum_{j \neq m}^{n} R_{i j}^{L}-R_{i j}^{D}
\end{aligned}
$$

The second line of Equation (A.3) shows that in addition to the terms that were in the parent funding equation before, $F_{i j}^{*}$ is also a function of $L_{i j}^{*}$ and the price margin $R_{i j}^{L}-R_{i j}^{D}$ of foreign affiliate $j$, as well as the sums of the amount of local lending and price margins of all other affiliates $j \neq m$ of parent $i$. We do not claim to empirically identify the system of equations indicated by Equations (A.2) and (A.3). Instead, we aim to show that our original results still hold after controlling for the dependence of the local lending by affiliates decision on the parent funding decision, and vice versa.

\section{References}

Ashcraft, A. B. (2006) New evidence on the lending channel, Journal of Money, Credit, and Banking 38, 751-775.

Aviat, A. and Coeurdacier, N. (2007) The geography of trade in goods and asset holdings, Journal of International Economics 71, 22-51.

Barth, J., Caprio, G., and Levine, R. (2001) The regulation and supervision of banks around the world: A new database. World Bank Working Paper (2588).

Benston, G., Hanweck, G., and Humphrey, D. (1982) Scale economies in banking, Journal of Money, Credit, and Banking 14, 435-546.

Berger, A., Demirgüç-Kunt, A., Levine, R., and Haubrich, J.G. (2004) Bank concentration and competition: An evolution in the making, Journal of Money, Credit and Banking 36, 433-451.

Buch, C. M., Koch, C. T., and Koetter, M. (2011a) Crises, rescues, and policy transmission through international banks. Discussion Paper of Deutsche Bundesbank 15.

Buch, C. M., Koch, C. T., and Koetter, M. (2011b) Size, productivity, and international banking, Journal of International Economics 85, 329-334.

Buch, C. M., Koch, C. T., and Koetter, M. (2014) Should I stay or should I go? Bank productivity and internationalization decisions, Journal of Banking and Finance 42, 266-282.

Campello, M. (2002) Internal capital markets in financial conglomerates: Evidence from small bank response to monetary policy, Journal of Finance 57, 2773-2805.

Carbó, S., Humphrey, D., Maudos, J., and Molyneux, P. (2009) Cross-country comparisons of competition and pricing power in European banking, Journal of International Money and Finance 28, 115-135.

Cetorelli, N. and Goldberg, L. (2012a) Banking globalization and monetary transmission, Journal of Finance 67, 1811-1843.

Cetorelli, N. and Goldberg, L. (2012b) Follow the money: Quantifying domestic effects of foreign bank shocks in the great recession, American Economic Review: Papers \& Proceedings 102, 213-218.

Cetorelli, N. and Goldberg, L. (2012c) Liquidity management of U.S. global banks: Internal capital markets in the great recession, Journal of International Economics 88, 299-311. 
Claessens, S. and van Horen, N. (2014a) Foreign banks: Trends and impact, Journal of Money, Credit, and Banking 46, 295-326.

Claessens, S. and van Horen, N. (2014b) Location decisions of foreign banks and competitor remoteness, Journal of Money, Credit, and Banking 46, 145-170.

Craig, B. R. and Dinger, V. (2013) Deposit market competition, wholesale funding, and bank risk, Journal of Banking and Finance 37, 3295-3732.

Cremers, K., Huang, R., and Sautner, Z. (2011) Internal capital markets and corporate politics in a banking group, Review of Financial Studies 24, 358-401.

De Blas, B. and Russ, K. (2013) All banks great, small, and global: Loan pricing and foreign competition, International Review of Economics and Finance 26, 4-24.

De Haas, R. and Van Horen, N. (2013) Running for the exit: International bank lending during a financial crisis, Review of Financial Studies 26, 244-285.

De Haas, R. T. and Van Lelyveld, I. P. (2010) Internal capital markets and lending by multinational bank subsidiaries, Journal of Financial Intermediation 19, 1-25.

De Haas, R. T. and Van Lelyveld, I. P. (2014) Multinational banks and the global financial crisis: Weathering the perfect storm?, Journal of Money, Credit, and Banking 46, 333-364.

Degryse, H. and Ongena, S. (2005) Distance, lending relationships, and competition, Journal of Finance 60, 231-266.

Fiorentino, E., Koch, C., and Rudek, W. (2010) Microdatabase: External position reports of German banks. Deutsche Bundesbank, Frankfurt a.m.

Freixas, X. and Rochet, J.-C. (2008) Microeconomics of Banking, 2nd edition. MIT Press, Cambridge.

Frey, R. and Kerl, C. (2015) Multinational banks in the crisis: Foreign affiliate lending as a mirror of funding pressure and competition on the internal capital market, Journal of Banking and Finance 50, 52-68.

Gambacorta, L. (2005) Inside the bank lending channel, European Economic Review 49, $1737-1759$.

Nachum, L. (2003) Liability of foreigness in global competition? Financial services affiliates in the City of London, Strategic Management Journal 24, 1187-1208.

Niepmann, F. (2013) Banking across borders with heterogeneous banks. Federal Reserve Bank of New York Staff Reports 609.

Niepmann, F. (2015) Banking across borders, Journal of International Economics 96, 244-265.

Ongena, S., Popov, A., and Udell, G. F. (2012) When the cat's away the mice will play: Does regulation at home affect bank risk-taking abroad?, Journal of Financial Economics 108, 727-750.

Park, K. and Pennacchi, G. (2009) Harming depositors and helping borrowers: The disparate impact of bank consolidation, Review of Financial Studies 22, 1-40.

Popov, A. and Udell, G. F. (2012) Cross-border banking, credit access, and the financial crisis, Journal of International Economics 87, 147-161.

Stiglitz, J. E. and Weiss, A. (1981) Credit rationing in markets with imperfect information, American Economic Review 71, 393-410.

Wooldridge, J. (2010) Econometric Analysis of Cross Section and Panel Data, 2nd edition. MIT Press, Cambridge, Massachusetts.

Yeaple, R. (2009) Firm heterogeneity and the structure of U.S. multinational activity, Journal of International Economics 78, 206-215. 